\title{
German evidence-based guidelines for the treatment of Psoriasis vulgaris (short version)
}

\author{
A. Nast · I. Kopp · M. Augustin - K. B. Banditt - W. H. Boehncke · M. Follmann - M. Friedrich • \\ M. Huber · C. Kahl · J. Klaus · J. Koza - I. Kreiselmaier · J. Mohr · U. Mrowietz · H. M. Ockenfels • \\ H. D. Orzechowski $\cdot$ J. Prinz $\cdot$ K. Reich $\cdot$ T. Rosenbach $\cdot$ S. Rosumeck $\cdot$ M. Schlaeger $\cdot$ \\ G. Schmid-Ott $\cdot$ M. Sebastian $\cdot$ V. Streit $\cdot$ T. Weberschock $\cdot$ B. Rzany
}

Received: 13 February 2007/Accepted: 14 February 2007/Published online: 12 May 2007

(C) Deutsche Dermatologische Gesellschaft 2007

\begin{abstract}
Psoriasis vulgaris is a common and chronic inflammatory skin disease which has the potential to significantly reduce the quality of life in severely affected patients. The incidence of psoriasis in Western industrialized countries ranges from 1.5 to $2 \%$. Despite the large variety of treatment options available, patient surveys have revealed insufficient satisfaction with the efficacy of available treatments and a high rate of medication noncompliance. To optimize the treatment of psoriasis in Germany, the Deutsche Dermatologische Gesellschaft and the Berufsverband Deutscher Dermatologen (BVDD) have initiated a project to develop evidence-based guidelines for the management of psoriasis. The guidelines focus on induction therapy in cases of mild, moderate, and severe plaque-type psoriasis in adults. The short version of the guidelines reported here consist of a series of therapeutic recommendations that are based on a systematic literature search and subsequent discussion with experts in the field; they have been approved by a team of dermatology experts. In addition to the therapeutic recommendations provided in this short version, the full version of the guidelines includes information on contraindications, adverse events, drug interactions, practicality, and costs as well as detailed
\end{abstract}

With kind permission of Deutsche Dermatologische Gesellschaft.

An enhanced version of these guidelines has been published with Blackwell in 2006.

A. Nast $(\bowtie)$

Division of Evidence Based Medicine (dEBM),

Klinik für Dermatologie, Venerologie, Allergologie,

Charité-Universitätsmedizin Berlin,

Schumannstrasse 20/21,

10117 Berlin, Germany

e-mail: info@psoriasis-leitlinie.de information on how best to apply the treatments described (for full version, please see Nast et al., JDDG, Suppl 2:S1S126, 2006; or http://www.psoriasis-leitlinie.de).

Keywords Evidence-based guidelines .

Psoriasis vulgaris · Treatment

\section{Introduction}

The Deutsche Dermatologische Gesellschaft (DDG) and the Berufsverband Deutscher Dermatologen (BVDD) have initiated a project to develop evidence-based guidelines for the treatment of plaque psoriasis. The full version of the Guidelines has been published in the Journal der Deutschen Dermatologischen Gesellschaft (JDDG 2006 Suppl 2) and is available at http://www.psoriasis-leitlinie.de [149]. This article summarizes the key points of the Guidelines.

\section{Background}

Psoriasis vulgaris is a common and chronic inflammatory skin disease which has the potential to significantly reduce the quality of life in severely affected patients. The incidence of psoriasis in Western industrialized countries is 1.5-2\% [2]. Studies on the impairment of life quality have shown that, depending on the severity of the disease, a significant burden may exist in the form of a disability or psychosocial stigmatization [3]. Patient surveys have shown that the mental and physical impairment associated with psoriasis is comparable to that of other significant chronic conditions, such as type 2 diabetes or chronic respiratory diseases [4].

Patient surveys have shown that only $25 \%$ of psoriasis patients are highly satisfied with the outcome of their treatment, another 50\% indicate moderate satisfaction, and approximately $20 \%$ report low treatment satisfaction [5]. In 
addition, there is a high non-compliance rate in the intake of medication of up to $40 \%$ [1].

Experience has shown that treatment selection for patients with psoriasis vulgaris is more commonly based on traditional concepts than on evidence-based data on the efficacy of various therapeutic options. In addition, it appears that systemic therapies are occasionally not applied in situations where they are needed due to the increased effort involved in monitoring the patients for unwanted side effects and possible interactions with other drugs.

\section{Goal of the Guidelines}

The overall objective of the Guidelines is to provide dermatologists in clinics and private practice with an accepted

\section{Kopp}

Ständige Kommission Leitlinien der AWMF,

c/o Philipps-Universität Marburg,

Institut für Theoretische Chirurgie,

Marburg, Germany

\section{Augustin}

Universitätsklinikum Hamburg-Eppendorf,

Klinik und Poliklinik für Dermatologie und Venerologie,

Hamburg, Germany

\section{K. B. Banditt}

Klinik für Dermatologie, Venerologie und Allergologie,

Charité-Universitätsmedizin Berlin,

Berlin, Germany

W. H. Boehncke $\cdot$ T. Weberschock

Zentrum der Dermatologie und Venerologie,

Klinikum der Johann Wolfgang Goethe Universität,

Frankfurt am Main, Germany

\section{Follmann}

Division of Evidence Based Medicine (dEBM),

Klinik für Dermatologie, Venerologie und Allergologie,

Charité-Universitätsmedizin Berlin

[since 1 February 2005: Institut für Qualität und

Wirtschaftlichkeit im Gesundheitswesen (IQWiG)],

Cologne, Germany

\section{Friedrich}

Klinik für Dermatologie, Venerologie und Allergologie, Charité-Universitätsmedizin Berlin

[since 1 January 2006: Intendis $\mathrm{GmbH}$ ],

Berlin, Germany

M. Huber · H. D. Orzechowski

Institut für Klinische Pharmakologie und Toxikologie,

Charité-Universitätsmedizin Berlin,

Berlin, Germany

C. Kahl $\cdot$ S. Rosumeck $\cdot$ B. Rzany

Division of Evidence Based Medicine (dEBM),

Klinik für Dermatologie, Venerologie,

Allergologie, Charité-Universitätsmedizin Berlin,

Schumannstrasse 20/21,

10117 Berlin, Germany and evidence-based decision-making tool for the selection and implementation of a suitable and efficacious treatment for patients with psoriasis vulgaris. The focus of the Guidelines is on the induction therapy of mild, moderate, and severe plaque-type psoriasis in adults.

1. Physicians' personal experiences and traditional therapeutic concepts should be supplemented and, if necessary, replaced by an evidence-based assessment of the efficacy of individual therapies in psoriasis vulgaris.

2. The guidelines provide in-depth explanations of the available systemic and topical treatments for psoriasis, including the different photo- and photochemical therapies, and provide detailed descriptions of the administration and safety aspects.

\author{
J. Klaus · J. Koza \\ Deutscher Psoriasis Bund e.V, \\ Hamburg, Germany \\ I. Kreiselmaier · U. Mrowietz \\ Klinik für Dermatologie, Venerologie, Allergologie, \\ Universitätsklinikum Schleswig-Holstein, Campus Kiel, \\ Kiel, Germany
}

J. Mohr

Abteilung Dermatologie und Venerologie,

Hautklinik und Poliklinik der Georg-August-Universität

Göttingen, Göttingen, Germany

H. M. Ockenfels

Haut- u. Allergieklinik, Klinikum Hanau,

Hanau, Germany

J. Prinz

Klinik und Poliklinik für Dermatologie und Allergologie, Klinikum der Ludwig Maximilian Universität München, Munich, Germany

K. Reich

Abteilung Dermatologie und Venerologie,

Hautklinik und Poliklinik der Georg-August-Universität

Göttingen (current: Dermatologikum Hamburg,

Prof. Steinkraus und Partner),

Göttingen, Germany

T. Rosenbach

Osnabrück, Germany

M. Schlaeger

Oldenburg, Germany

G. Schmid-Ott

Abteilung Psychosomatik und Psychotherapie,

Medizinische Hochschule Hannover,

Hannover, Germany

M. Sebastian

Mahlow, Germany

V. Streit

Buchholz, Germany 
3. By providing background information on the profile of the available drugs, including efficacy, safety, and aspects of practicality and costs, the Guidelines should facilitate the process of selecting an appropriate treatment for each individual patient. This should help increase compliance and optimize the benefit/risk ratio of psoriasis therapies.

\section{Methods}

A detailed description of the methodology employed in developing the Guidelines can be found in the Method Report on the Guidelines (http://www.psoriasis-leitlinie.de).

\section{Basis of data}

A systematic search of the literature was carried out in May 2005 with the objective of assessing the effectiveness of individual therapeutic options. This search yielded 6,224 publications of which 142 studies fulfilled the inclusion criteria for the Guidelines (see Box 1) and were therefore included in the assessment of the effectiveness of the relevant treatment. Various other aspects were evaluated on the basis of information presented in available literature, without a systematic analysis, and the years of personal experience of the experts.

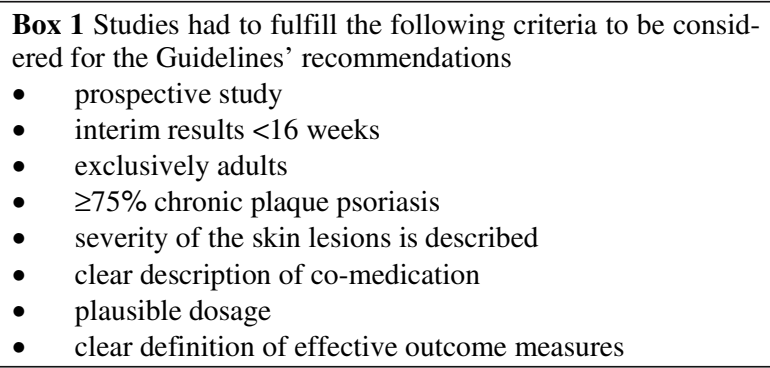

\section{Evidence assessment}

The efficacy and effectiveness of each intervention was evaluated using evidence-based criteria.

The methodological quality of each individual study was assessed using the following grades of evidence (GE):

$A_{1}$ Meta-analysis that includes at least one randomized study with grade $\mathrm{A}_{2}$ evidence. In addition, the results of the different studies included in the meta-analysis must be consistent with one another.

$\mathrm{A}_{2}$ A high-quality (e.g. sample-size calculation, flow chart, intention-to-treat (ITT) analysis, sufficient size) randomized, double-blind comparative clinical study.

B Randomized clinical study of lesser quality or other comparative study (non-randomized, cohort, or casecontrol study).
C Non-comparative study.

D Expert opinion.

Individual interventions (i.e., as monotherapy) were rated according to the following levels of evidence (LE):

1. Intervention is supported by studies with grade $A_{1}$ evidence or studies with grade $A_{2}$ evidence whose results are predominantly consistent with one another.

2. Intervention is supported by studies with grade $A_{2}$ evidence or studies with grade $\mathrm{B}$ evidence whose results are predominantly consistent with one another.

3. Intervention is supported by studies with grade B evidence or studies with grade $\mathrm{C}$ evidence whose results are predominantly consistent with one another.

4. Little or no systematic empirical evidence

\section{Passages requiring consensus}

The Guidelines Group defined particularly relevant sections as passages requiring consensus and approved these in the framework of the consensus conferences. These sections are highlighted in grey boxes.

\section{Therapeutic recommendation}

A distinct rating of the therapeutic options or a strict clinical algorithm cannot be defined for the treatment of psoriasis vulgaris. The criteria for selecting a particular therapy are complex. The decision for a specific treatment should be based on the profile of the available drugs and the characteristics of a given patient. The decision for or against a therapy remains a case-by-case decision. These Guidelines provide a reasonable form of assistance in deciding on a suitable therapy and are an instrument for optimizing the required therapeutic process.

The recommendations formulated in the text are supported graphically in selected key recommendations by the following indications of the strength of the therapeutic recommendation:

$\uparrow \uparrow \quad$ Measure is highly recommended

$\uparrow \quad$ Measure is recommended

$\rightarrow \quad$ Neutral

$\downarrow \quad$ Measure is not recommended

$\downarrow \downarrow \quad$ Measure is highly inadvisable

The strength of the recommendation reflects both a treatment's efficacy and the level of evidence supporting it as well as aspects of safety, practicality, and the cost/ benefit ratio. A consensus on the strength of the recommendation was reached during the Consensus Conference. 


\section{Results}

Therapeutic options are named and discussed in alphabetical order.

\section{Therapeutic strategies}

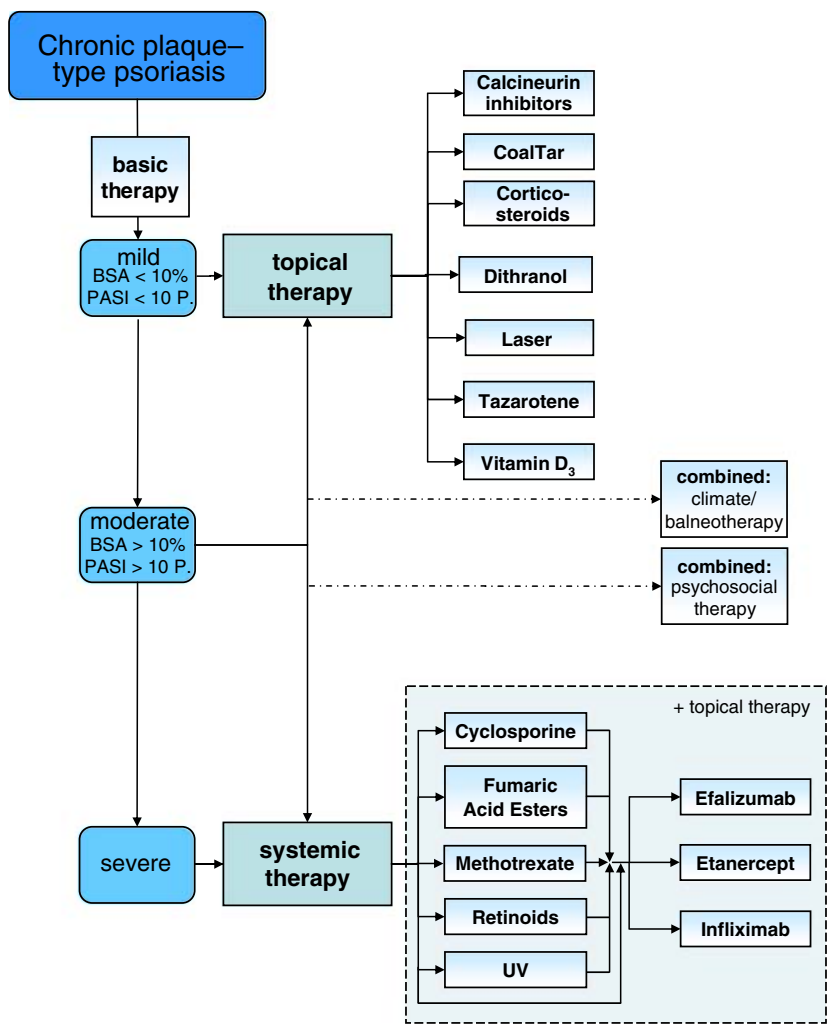

Fig. 1 Overview of the therapeutic options evaluated for chronic plaque psoriasis (the therapeutic options are listed alphabetically and do not represent a ranking)

\section{Evaluation of topical and systemic therapies in tabular form}

These tables are intended to provide a rough orientation for evaluating the therapeutic options. Cumulative calculations of the individual aspects for the overall evaluation of the therapeutic options are not possible and cannot be drawn upon for the final analysis of a therapeutic option. The product assessment for each individual patient may deviate greatly. A direct comparison between systemic and topical therapies is not possible because of the different severity of the psoriasis lesions of patients treated with topical or systemic treatments. The evaluations reported here were made on the basis of data extracted from the literature and expert opinions.

For further details refer to the Methods Report at www.psoriasis-leitlinie.de
Topical monotherapy

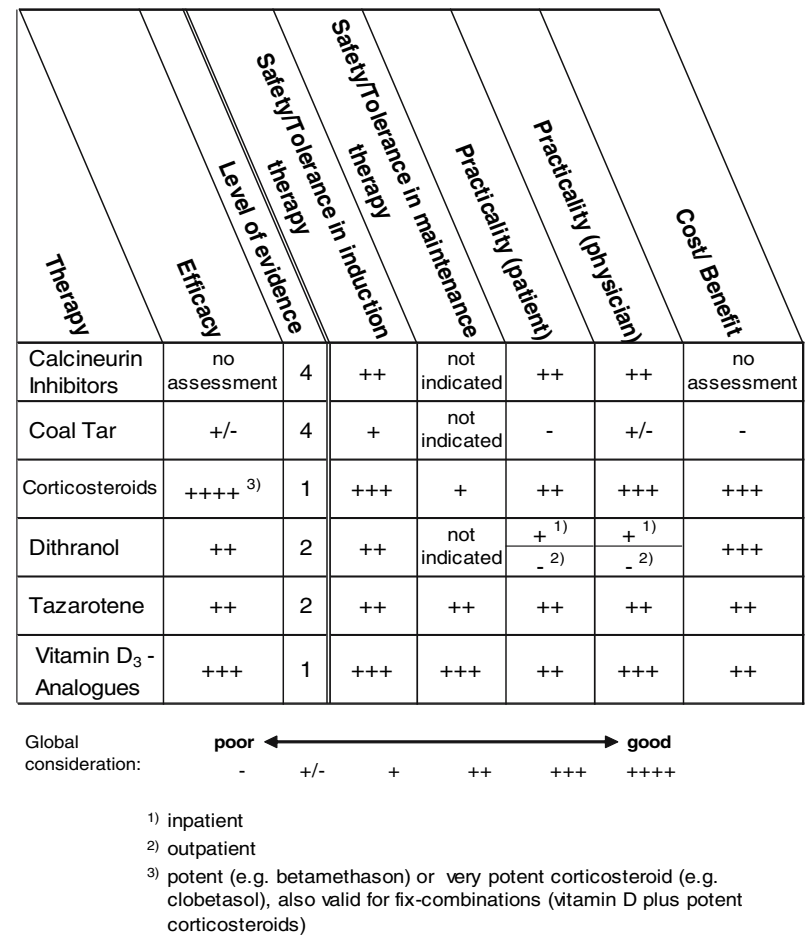

Phototherapy and systemic monotherapy



1) systemic PUVA

2) Bath- / Cream- PUVA

3) for women in childbearing age the therapy with retinoids is generally not recommended

4) for $2 \times 25 \mathrm{mg}$

5) for $2 \times 50 \mathrm{mg}$ 
(a) Efficacy The evaluation of the efficacy column reflects the percentage of patients who achieved a reduction in the baseline Psoriasis Area and Severity Index (PASI) of $\geq 75 \%$.

\begin{tabular}{lll}
\hline Scale & Systemic therapy & Topical therapy \\
\hline++++ & Approx. $90 \%$ & Approx. 60\% \\
+++ & Approx. 70\% & Approx. 45\% \\
++ & Approx. 50\% & Approx. 30\% \\
+ & Approx. 30\% & Approx. 15\% \\
$+/-$ & Approx. 10\% & Approx. 5\% \\
- & Not defined & Not defined \\
\hline
\end{tabular}

The evidence level applies only to the estimate of efficacy.

(b) Safety/tolerance in induction therapy or maintenance therapy This refers to the risk of occurrence of severe adverse drug reactions or the probability of adverse drug reactions that would result in the discontinuation of therapy.

(c) Practicality (Patient) This evaluation analyzes the effort involved in handling and administrating the treatment regimen by the patient.

(d) Practicality (Physician) This aspect considers the amount of work (documentation, explanation, monitoring), personnel and equipment needs, time for physician/patient interaction, remuneration of therapeutic measures, invoicing difficulties/risk of recourse claims from the health insurance companies.

(e) Cost/benefit Consideration of the costs of an induction therapy or a maintenance therapy.

The evaluations of safety/tolerance in induction therapy or maintenance therapy as well as practicality for the physician or patient and the cost/benefit were performed using a scale ranging from poor (-) to good (++++). The gradation between these two extremes was made based on expert opinion and unsystematic literature search. A level of evidence was not given for these evaluations since no systematic literature review was performed.

\section{Evaluation of topical therapies}

\section{Calcineurin inhibitors}

Table 1 Tabular summary

\section{Calcineurin inhibitors}

First approved in Germany

Pimecrolimus (Elidel ${ }^{\circledR}$ ) 2002 (Atopic dermatitis, not approved for psoriasis vulgaris)

Tacrolimus (Protopic ${ }^{\circledR}$ ) 2002 (Atopic dermatitis, not approved for psoriasis vulgaris)

Recommended initial Pimecrolimus cream: $1 \times$ to $2 \times$ daily dosage

Tacrolimus: $1 \times$ to $2 \times$ daily (application on the face: Begin with $0.03 \%$ salve; increase later dosage to $0.1 \%$ salve)

Recommended Individual therapeutic adjustment maintenance dosage

Expected beginning After approximately 2 weeks of clinical effect

Response rate

Important contraindications

Important adverse drug reactions (ADRs)

Important drug interactions

Other

No data available

Pregnancy and nursing (due to lack of experience) skin infections, immune suppression

Burning sensation on skin, skin infections

None known

Cave: Do not combine with phototherapy! Photoprotection!

\section{General assessment}

Of the three studies with topical calcineurin inhibitors (pimecrolimus, tacrolimus) assessed, one study met the inclusion criteria of the Guidelines. ${ }^{[6]}$ For that reason, the efficacy of psoriasis vulgaris treatment with topical calcineurin inhibitors can currently only be rated with a level of evidence of 4 . Based on the studies to date, there is no evidence that monotherapy with calcineurin inhibitors is beneficial. Other studies have, however, demonstrated that topical calcineurin inhibitors can be beneficial in the treatment of psoriasis vulgaris in corticosteroid-sensitive areas such as the face, intertriginous areas, and the anogenital region.

Since topical calcineurin inhibitors are not approved treatment for psoriasis vulgaris, treatment may only be performed in off-label use.

The tolerance is generally good. Data on long-term safety are not available due to the relatively short-period of availability.

Broad usage as a first-line therapy does not appear to be justified by the existing data. 


\section{Therapeutic recommendation}

Pimecrolimus and tacrolimus administered topically $1 \times$ to $2 \times$ per day can be considered to be a reasonable supplementary treatment of psoriasis vulgaris at specific locations of the body, such as the face, intertriginous areas and anogenital region (e.g. in interval therapy) or as a replacement for topical corticosteroids.

Watch for unwanted side effects such as burning and skin irritations.

Use at other body sites is not recommended.

\section{Corticosteroids}

Table 2 Tabular summary

Corticosteroids

First approved in 1956 (Psoriasis vulgaris)
Germany

Recommended control None parameters

Recommended initial One to two times daily dosage

Recommended Gradual reduction following onset of effect maintenance dosage

Expected beginning After 1-2 weeks of clinical effect

Response rate

Betamethasone dipropionate, two times daily: marked improvement or clearance of the skin lesions in $46-56 \%$ patients after 4 weeks (LE 1)

Important contraindications

Important ADRs

Skin infections, rosacea, perioral dermatitis

Skin infections, perioral dermatitis, skin atrophy, hypertrichosis, striae

Important drug None interactions

Other

\section{General assessment}

Of the 100 studies assessed for a monotherapy with corticosteroids, 20 fulfilled the Guidelines' inclusion criteria. ${ }^{[17-36]}$

With the application of potent corticosteroids (betamethasone dipropionate, $2 \times$ daily), $46-56 \%$ of the patients showed a clear improvement or a complete clearing of the skin lesions.

Therapy with very potent corticosteroids (clobetasol-17-propionate, $2 \times$ daily) demonstrated similar results in $68-89 \%$ of the patients in most studies.

Topical corticosteroids demonstrate a good to very good efficacy in the treatment of mild to moderate psoriasis vulgaris (LE 1).

The combination of topical corticosteroids with salicylic acid enhances the therapeutic effect.

Combination with other systemic or topical therapies also results in improved rates of remission. The most common combination is with topical vitamin $\mathrm{D}_{3}$ derivates.

There are no severe adverse drug reactions in the induction phase. Care must be taken regarding the development of typical adverse corticosteroid effects such as skin atrophies or teleangiectases in cases of longer application and in particularly sensitive areas.

The practicality for physicians and patients is good.

\section{Therapeutic recommendation}

Therapy with topical corticosteroids is highly recommended for mild to moderate psoriasis vulgaris as a combination therapy with systemic therapies or other topical therapies.

The selection of the class of corticosteroids must be adjusted for the specific skin area to be treated. 


\section{Coal tar}

Table 3 Tabular summary

\section{Coal tar}

\section{First approved in Germany}

\section{Recommended control parameters}

Recommended initial dosage

Recommended maintenance dosage

Expected beginning of clinical effect

Response rate

Important contraindications

Important ADRs

Important drug interactions

Other
Listed active ingredient since 2000 (DAC on page 170), historical application, various tar-containing externals are licensed as drugs, application of tar as anti-psoriatic following publication by Goeckermann in 1925

After long-term application/application on large areas: if needed clinical controls for potential development of skin carcinoma

5-20\% salve preparations or gels for local therapy, $1 \times$ daily

No long-term application (max. 4 weeks, DAC 2000)

After 4-8 weeks, efficacy improves in combination with UV application

There is insufficient data available on the response rate as a monotherapy (LE 4)

Pregnancy and nursing

Color, odor, carcinogenic risk, phototoxicity-which is part of the desired effect

Not known with topical use

DAC 2000 (on page 170), Hazardous Goods Directive Appendix 4 No. 13

\section{General assessment}

Of 19 studies assessed, four fulfilled the Guidelines' inclusion criteria. ${ }^{[37-40]}$ Since only one monotherapy study was evaluated (with three patients), it is not possible to make a clear statement about the efficacy of monotherapy (LE 4).

Coal tar is used in clinical studies in combination with phototherapy.

In the combination therapy with UV light, a reduction of the PASI by about $75 \%$ was achieved in $45-80 \%$ of study participants after 15-20 applications. The additional effect of coal tar in combination therapy with UV compared to UV therapy alone has not been proven. The acceptance of coal tar is low due to its color and odor.

Magistral preparations may be less expensive than comparable manufactured products.

\section{Therapeutic recommendation}

The efficacy of coal tar treatment in psoriasis vulgaris has not been demonstrated, either as monotherapy or combination therapy. For this reason, coal tar is not recommended for this indication.

In view of the low-risk and more practical therapeutic alternatives, a monotherapy of psoriasis vulgaris with coal tar is obsolete.

Only after careful consideration of the therapeutic benefit and after low-risk therapeutic alternatives have failed should coal tar be used in combination with UVB in exceptional refractory cases of psoriasis vulgaris 


\section{Dithranol}

Table 4 Tabular summary

Dithranol

First approved in Germany

Psoralon

1983 (Psoriasis vulgaris)

Psoradexan

Micanol

Recommended control parameters

Recommended initial dosage

Recommended maintenance dosage

Expected beginning of clinical effect

Response rate

Important contraindications

Important ADRs

Important drug interactions

Other

After 2-3 weeks

$-$

\section{General assessment}

Of 63 studies assessed for a monotherapy with dithranol, 11 fulfilled the Guidelines' inclusion criteria.

The results of the studies assessed showed total remission (PASI reduction $100 \%$ ) in $30-70 \%$ of the patients and partial remission (PASI reduction $75 \%$ ) in $26-100 \%$ of patients after 5-8 weeks of treatment (LE 2).

The efficacy can be increased further if either calcipotriol creams or a UVB phototherapy is combined with dithranol.

Dithranol, one of the oldest topical therapeutics for psoriasis vulgaris, is still a treatment for mild to moderate psoriasis vulgaris as an out-patient monotherapy and as part of combination therapies for moderate psoriasis vulgaris in hospitalized and day clinic patients.

The therapy is very safe. Although skin irritations, burning, erythema and intermittent brown discolorations are observed, there are no systemic adverse drug reactions.

The practicality is clearly limited for outpatient use. The practicality for the physician, especially when treating inpatients, and the costbenefit ratio are positive.

Marked improvement or clearance of skin lesions in $30-50 \%$ of the patients (LE 2)

Acute, erythrodermic forms of psoriasis vulgaris; pustular psoriasis

Burning and reddening of the skin in $>10 \%$

\section{Therapeutic recommendation}

Monotherapy for patients with mild and moderate psoriasis vulgaris is recommended for induction therapy during hospitalization

And conditionally recommended as an outpatient treatment.

Because it is more practical, short-contact therapy should be given preference. In hospitalized patients, classical dithranol therapy with $2 x$ daily application without immediate rinsing can be easily performed.

The therapy should be performed for 4 and conditionally recommended as an outpatient treatment for 4-8 weeks. Maintenance or long-term therapy with dithranol is not practical and offers no advantages.

In the treatment of severe forms of psoriasis vulgaris, combination treatment with phototherapy or other topical preparations (calcipotriol) is recommended because of the improved response rate. 


\section{Tazarotene}

Table 5 Tabular summary

\begin{tabular}{|c|c|}
\hline \multicolumn{2}{|l|}{ Tazarotene } \\
\hline $\begin{array}{l}\text { First approved in } \\
\text { Germany }\end{array}$ & 1997 (psoriasis vulgaris) \\
\hline $\begin{array}{l}\text { Recommended } \\
\text { control parameters }\end{array}$ & Check development of skin irritations \\
\hline $\begin{array}{l}\text { Recommended initial } \\
\text { dosage }\end{array}$ & $\begin{array}{l}\text { Begin with one treatment daily of } \\
\text { tazarotene gel } 0.05 \% \text { in the evening for } \\
\text { approximately } 1-2 \text { weeks }\end{array}$ \\
\hline $\begin{array}{l}\text { Recommended } \\
\text { maintenance } \\
\text { dosage }\end{array}$ & $\begin{array}{l}\text { If necessary continue for } 1-2 \text { weeks with } \\
\text { tazarotene gel } 0.1 \%\end{array}$ \\
\hline $\begin{array}{l}\text { Expected beginning } \\
\text { of clinical effect }\end{array}$ & After $1-2$ weeks \\
\hline Response rate & $\begin{array}{l}\text { After } 12 \text { weeks therapy with } 0.1 \% \\
\text { tazarotene gel improved findings of at } \\
\text { least } 50 \% \text { in approximately } 50 \% \text { of the } \\
\text { patients (LE 2) }\end{array}$ \\
\hline $\begin{array}{l}\text { Important } \\
\text { contraindications }\end{array}$ & Pregnancy, nursing \\
\hline Important ADRs & $\begin{array}{l}\text { Pruritus, burning sensation of skin, } \\
\text { erythema, irritation }\end{array}$ \\
\hline $\begin{array}{l}\text { Important drug } \\
\text { interactions }\end{array}$ & $\begin{array}{l}\text { Avoid concomitant use of preparations } \\
\text { with irritating and drying properties }\end{array}$ \\
\hline Other & - \\
\hline
\end{tabular}

\section{General assessment}

Of the nine studies assessed, six fulfilled the Guidelines' inclusion criteria. $^{[41-46]}$

After daily treatment with tazarotene $0.1 \%$, approximately $50 \%$ of the patients showed at least a $50 \%$ improvement of the skin lesions after about 12 weeks of treatment (LE 2).

An optimization of the therapeutic success and a reduction of the frequent skin irritations can be attained with a combination of tazarotene and topical corticosteroids.

There are no severe adverse drug reactions. However, contact with healthy skin should be avoided to prevent skin irritation.

\section{Therapeutic recommendation}

The topical application of tazarotene is recommended for the treatment of mild to moderate psoriasis vulgaris.

An application of tazarotene in the evening in combination with a corticosteroid in the morning is recommended as a combination therapy to reduce irritation and increase efficacy.

Vitamin $D_{3}$ and analogues

Table 6 Tabular summary

Vitamin $\mathrm{D}_{3}$ and analogues

First approved in Germany

Calcipotriol

Tacalcitol

Calcitriol

Calcipotriol/ Betamethasone

Recommended control parameters

Recommended initial dosage

Recommended maintenance dosage

Expected beginning of clinical effect

Response rate

Important contraindications

Important ADRs

Important drug interactions

Other

\section{2 (Psoriasis vulgaris)}

1994 (Psoriasis vulgaris)

1999 (Psoriasis vulgaris)

2002 (Psoriasis vulgaris)

Monitor for skin irritations

Calcipotriol: $1 \times$ to $2 \times$ daily to affected locations, up to a maximum of $30 \%$ of the body surface

Tacalcitol: $1 \times$ daily to affected locations, up to a maximum of $20 \%$ of the body surface

Calcitriol: $2 \times$ daily to affected locations, up to a maximum of $35 \%$ of the body surface

Calcipotriol: $1 \times$ to $2 \times$ daily, up to $100 \mathrm{~g} /$ week for up to 1 year

Tacalcitol: $1 \times$ daily for 8 weeks, for up to 18 months, on a maximum of $15 \%$ of the body surface with up to $3.5 \mathrm{~g}$ daily

Calcitriol: insufficient experience with the application for more than 6 weeks

After 1-2 weeks

Between 30 and $50 \%$ of the patients demonstrated a marked improvement or clearance of the lesions after 4-6 weeks (LE 1)

Diseases with abnormal calcium metabolism, severe liver and renal diseases

Skin irritation (reddening, itching, burning)

Drugs which elevate the calcium levels, (e.g. thiazide diuretics), no concomitant application of topical salicylic acid preparations (inactivation)

Exposure to UV light results in inactivation of the vitamin $\mathrm{D}_{3}$-analogues 


\section{General assessment}

Of the 39 studies considered, 11 fulfilled the Guidelines' inclusion criteria. ${ }^{[14,22-25,47-52]}$

The majority of available data is on calcipotriol. After vitamin $\mathrm{D}_{3}$ analogue treatment of mild to moderate psoriasis vulgaris, 30-50\% of the patients showed a marked improvement or clearance of the skin lesions within a few weeks (LE 1).

The efficacy and tolerance can be further improved if the Vitamin $\mathrm{D}_{3}$-analogue is combined with topical corticosteroids during the initial therapy.

In the treatment of severely affected patients, topical therapy with vitamin $D_{3}$-analogues demonstrated synergistic effects with a UV phototherapy and systemic cyclosporine therapy.

The topical vitamin $\mathrm{D}_{3}$-analogues are generally well-tolerated and practicable for the physician and the patient. Temporary skin irritations may limit the use, especially on the face or the intertriginous areas.

\section{Therapeutic recommendation}

Vitamin $\mathrm{D}_{3}$-analogues are the treatment of choice, especially for maintenance therapy in mild to moderate psoriasis vulgaris.

On the basis of the extensive study data and the superior efficacy, this recommendation is particularly true for calcipotriol. Because of its low irritating potential, the application of tacalcitol is particularly recommended for sensitive areas (e.g. face).

In the first weeks, use together with topical corticosteroids or as a fixed combination is superior to monotherapy with respect to efficacy and tolerance.

For moderate to severe psoriasis vulgaris, a combination of topical vitamin $\mathrm{D}_{3}$-analogues with UV phototherapy or a systemic therapy can be recommended.

\section{Phototherapy}

Table 7 Tabular summary

Phototherapy

First approved in Germany

Recommended control parameters

Recommended initial Individual dose depends on skin type; dosage options:

- UVB: $70 \%$ of minimum erythema dose (MED)

- Oral PUVA (photochemotherapy): $75 \%$ of the minimum phototoxic dose (MPD)

Recommended maintenance dosage

Expected beginning of clinical effect

Response rate

Important contraindications

- Bath/cream PUVA: 20-30\% of MPD

Increase according to degree of UV erythema

After 1-2 weeks

In $>75 \%$ of the patients PASI, 75 after 4-6 weeks (LE 2)

Photo-dermatoses/photosensitive diseases, skin malignancies, immunosuppression

Only PUVA: pregnancy and nursing

Important ADRs

Erythema, itching, blistering, malignancies

Only oral PUVA: nausea

Important drug interactions

Drugs causing phototoxicity or photoallergy

Other

Combination with topical preparations acts synergistically, PUVA may not be combined with cyclosporine 


\section{Instructions for application}

Pre-treatment

- The attending physician has to perform a complete skin examination, paying special attention to melanocytic nevi (especially if dysplastic) and cutaneous malignancies.

- The patient has to be informed about unwanted side effects and possible long-term risks - especially the therapy-related increased risk of skin cancer. Additional UV exposure as a result of leisure-time activities should be considered. Written informed consent must be obtained.

- Before starting oral PUVA therapy, an ophthalmologic examination and the prescription of UV sunglasses is required.

\section{During treatment}

- The UV dosages applied must be documented in precise physical units $\left(\mathrm{J} / \mathrm{cm}^{2}\right.$ or $\left.\mathrm{mJ} / \mathrm{cm}^{2}\right)$.

Regular monitoring of UV erythema must be performed for the purpose of dosage increase.

- The medical records should document therapeutic response, unwanted side effects, and accompanying treatments.

- Eye protection with UV glasses is generally required.

- If the areas chronically exposed to light (face, neck, backs of hands) and the genital region are free of lesions, these should be protected from exposure.

- Adequate protection from the sun must accompany therapy.

$\underline{\text { Post-treatment }}$

- Whenever a course of therapy is completed, the cumulative UV dosage and the number of treatments should be recorded and the patient has to be informed.

- Particularly in the case of patients with high cumulative UV dosage, a regular skin cancer examination should be performed for the patient's entire life.

\section{General assessment}

Of the 145 studies on monotherapy or combination therapy assessed, 25 studies on phototherapy, 32 studies on PUVA therapy, and five studies on therapeutic procedures with lasers fulfilled the Guidelines' inclusion criteria.

About three-quarters of all the patients treated with phototherapy attained at least a 75\% PASI score reduction after 4-6 weeks, and clearance was frequently achieved (LE 2).

Phototherapy represents a safe and very effective modality for the treatment of moderate to severe forms of psoriasis vulgaris. The onset of the clinical effects is within 2 weeks.

Of the unwanted side effects, UV erythema from overexposure is by far the most common and is observed frequently. With repeated or long-term application, the consequences of high, cumulative UV dosages (i.e. premature aging of the skin) must be taken into consideration. In addition, carcinogenic risk is associated with oral PUVA and is probable for local PUVA and UVB.

The practicality of the therapy is limited as a result of the spatial, financial, and human aspects as well as by time resources on the part of the physician as well as the amount of time required by the patient.

From the perspective of the cost-bearing institution, phototherapy has a good cost-benefit ratio. However, the potentially significant costs and time required of the patient must be noted.

\section{Therapeutic recommendation}

Phototherapy is recommended as an induction therapy for moderate to severe psoriasis vulgaris, above all for widespread involvement.

The side effects of specific types of radiation must be weighed. A possible subsequent risk of skin cancer is better documented for PUVA than for UVB.

Due to its low practicality and the association of longterm unwanted side effects with the cumulative UV doses, phototherapy is not suitable for long-term treatment.

Combination with topical vitamin $\mathrm{D}_{3}$-analogues is recommended to improve the response rate.

A recommendation for the common combination with dithranol and corticosteroids can only be given on the basis of clinical experience, but not on the basis of scientific data.

The use of Excimer Lasers should be limited to the targeted treatment of individual psoriatic plaques.

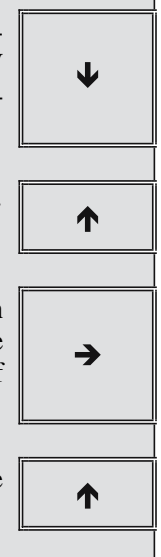




\section{Evaluation of systemic therapies}

\section{Efalizumab}

Table 8 Tabular summary

Efalizumab

\begin{tabular}{|c|c|}
\hline $\begin{array}{l}\text { First approved in } \\
\text { Germany }\end{array}$ & September 2004 (psoriasis vulgaris) \\
\hline $\begin{array}{l}\text { Recommended control } \\
\text { parameters }\end{array}$ & $\begin{array}{l}\text { Prior to therapy exclusion of significant } \\
\text { infections, complete blood count, } \\
\text { liver values }\end{array}$ \\
\hline $\begin{array}{l}\text { Recommended initial } \\
\text { dosage }\end{array}$ & $0.7 \mathrm{mg} / \mathrm{kg}$ body weight (BW) per week \\
\hline $\begin{array}{l}\text { Recommended } \\
\text { maintenance dosage }\end{array}$ & $1 \mathrm{mg} / \mathrm{kg} \mathrm{BW}$ per week \\
\hline $\begin{array}{l}\text { Expected beginning } \\
\text { of clinical effect }\end{array}$ & After $4-8$ weeks \\
\hline Response rate & $\begin{array}{l}\text { PASI } 75 \text { for approximately } 30 \% \text { of the } \\
\text { patients after } 12 \text { weeks (LE 1) }\end{array}$ \\
\hline $\begin{array}{l}\text { Important } \\
\text { contraindications } \\
\text { (limited selection) }\end{array}$ & $\begin{array}{l}\text { Chronic or acute infections, pregnancy, } \\
\text { malignant diseases, immune } \\
\text { deficiencies, no vaccinations before } \\
\text { or during treatment }\end{array}$ \\
\hline $\begin{array}{l}\text { Important ADRs (limited } \\
\text { selection) }\end{array}$ & $\begin{array}{l}\text { Flu-like injection reactions, } \\
\text { leukocytosis and lymphocytosis, } \\
\text { rebound, exacerbation and } \\
\text { arthralgia, thrombocytopenia }\end{array}$ \\
\hline $\begin{array}{l}\text { Important drug } \\
\text { interactions }\end{array}$ & Not known \\
\hline Other & $\begin{array}{l}\text { Stop therapy due to the risk of } \\
\text { exacerbation and rebound if a PASI } \\
\text { reduction of } 50 \% \text { is not achieved } \\
\text { after } 12 \text { weeks }\end{array}$ \\
\hline
\end{tabular}

\section{Instructions for application}

\section{Pre-treatment}

- Exclusion of severe systemic (acute and chronic) and local infections (e.g. abscesses)

- Reliable contraception and exclusion of pregnancy in women of childbearing age

- Patients should be made aware of the risks of and be monitored for severe infections

$\checkmark \quad$ Laboratory controls (see Table 3.5.1.1.2)

During treatment

- Exclusion of infections; the therapy should at least be temporarily discontinued when there is a suspicion of such.

- After 12 weeks of treatment, assessment of the therapeutic success: in case of good results (PASI $>50 \%$ improvement), treatment with efalizumab can be continued; otherwise, the treatment should be discontinued.

- In case of an exacerbation, another suitable psoriasis therapy should be introduced. In this case, other biologics should be considered.

- Laboratory controls (see Table 3.5.1.1.2)

Post-treatment

- Patients, who discontinue efalizumab should be subject to close follow-up.

- In cases of reoccurrence or exacerbation of the disease, the introduction of another suitable psoriasis treatment is recommended.

- Patients should be informed about the possibility of the occurrence of a rebound, which would make an immediate consultation necessary.

Table 9 Laboratory controls during treatment with efalizumab

\begin{tabular}{|lcccccccc|}
\hline $\begin{array}{l}\text { Period in months } \rightarrow \\
\text { Diagnostics } \downarrow\end{array}$ & Before 1 & 2 & 3 & 4 & 5 & 6 & 9 \\
\hline Complete blood count $^{\mathrm{a}}$ & $\mathrm{x}$ & $\mathrm{x}$ & $\mathrm{x}$ & $\mathrm{x}$ & $\mathrm{x}$ & $\mathrm{x}$ & $\mathrm{x}$ & $\mathrm{x}$ \\
\hline ALT, AST $^{\mathrm{b}}$ & $\mathrm{x}$ & \multicolumn{1}{c|}{$\mathrm{x}$} & & & & \\
\hline
\end{tabular}

${ }^{\mathrm{a}} \mathrm{Hb}$ (hemoglobin), HCT (hematocrit), erythrocytes, leukocytes, differential blood count, platelets

${ }^{\mathrm{b}}$ ALT alanine aminotransferase, AST aspartate aminotransferase 


\section{General assessment}

All six of the studies assessed in terms of the efficacy of therapy with efalizumab fulfilled the Guidelines' inclusion criteria. ${ }^{[101-106]}$

Approximately 30 and $40 \%$ of those patients with moderate to severe psoriasis vulgaris treated with efalizumab at a dose of 1 $\mathrm{mg} / \mathrm{kg}$ BW per week attained a PASI reduction of $>75 \%$ (LE 1) within 12 weeks and 24 weeks, respectively.

As a result of the only once-per-week subcutaneous injection and the only rarely required medical controls, the therapy is highly practicable for both the patient and the attending physician.

Based on current knowledge, efalizumab possesses a favorable safety profile.

A follow-up of a larger patient population for a longer period of time is necessary for a definitive assessment of the efficacy and safety as a long-term treatment.

Compared to other biologics, experience with efalizumab is significantly lower due to the smaller patient populations which have been treated with efalizumab.

Disease exacerbation during therapy or a rebound after therapy has been observed.

\section{Therapeutic recommendation}

Efalizumab is recommended for induction therapy of moderate to severe psoriasis vulgaris especially if other therapeutic options have not demonstrated sufficient therapeutic effect, are not tolerated, or are contraindicated.

Therapy should not be continued if an improvement of at least $50 \%$ of the initial findings is not observed after the first 12 weeks of treatment.

\section{Etanercept}

Table 10 Tabular summary

Etanercept

First approved in Germany

Recommended control parameters

Recommended initial dosage

Recommended maintenance dosage

Expected beginning of clinical effect

Response rate

Important contraindications (limited selection)

Important ADRs (limited Local reactions, infections selection)

Important drug interactions (limited selection)

Other

\section{Instructions for application}

\section{Pre-treatment}

- Exclusion of acute and chronic infections. An absolute exclusion of tuberculosis in accordance with the recommendations by the Paul Ehrlich Institute (www.pei.de)

- Reliable contraception and exclusion of pregnancy for women of child-bearing age

- Patients should be made aware of the risk of severe infections

During treatment

- At each visit, presence of infections should be excluded; the therapy should, at least temporarily, be discontinued in suspicious cases

- Monitoring for infections

- Etanercept therapy should be terminated or temporarily discontinued if there are signs of severe infection

- Discontinuation of therapy in case of onset of pregnancy

- Continued treatment with etanercept after 12 weeks if response is good, otherwise therapy should be discontinued

Post-treatment

None 
Table 11 Laboratory controls during treatment with etanercept

\begin{tabular}{|c|c|c|c|c|c|}
\hline $\begin{array}{l}\text { Period in months } \rightarrow \\
\text { Diagnostics } \downarrow\end{array}$ & before & 1 & 3 & 6 & 8 \\
\hline Diff. Blood count & $\mathrm{x}$ & $\mathrm{x}$ & $\mathrm{x}$ & $\mathrm{x}$ & $\mathrm{x}$ \\
\hline ALT, AST & $\mathrm{x}$ & $\mathrm{x}$ & $\mathrm{x}$ & $\mathrm{x}$ & $\mathrm{x}$ \\
\hline $\begin{array}{l}\text { Pregnancy test } \\
\text { (urine) }\end{array}$ & $x$ & & & & \\
\hline
\end{tabular}

\section{General assessment}

Of the four studies assessed, three fulfill the Guidelines' inclusion criteria. ${ }^{\text {II }}$

During etanercept therapy, approximately $35 \%$ of the patients attained a PASI reduction of $75 \%$ after 12 weeks with two subcutaneous doses of $25 \mathrm{mg}$ per week. With a therapy with $2 \times 50 \mathrm{mg}$ subcutaneous per week for 12 weeks approximately $50 \%$ of the patients attained a PASI reduction of $75 \%$ (LE 1).

Clinical experience has shown that clinical efficacy can be maintained in a long-term therapy for up to 24 weeks.

The therapy is practicable for both the patient and the physician. As a result of the large number of patients treated with etanercept for other indications, the risk of adverse drug reactions can be estimated very well.

\section{Therapeutic recommendation}

Etanercept is recommended for induction therapy for patients with moderate to severe psoriasis vulgaris, especially if other therapeutic options have not demonstrated satisfactory therapeutic success, are not tolerated, or are contraindicated.

If concomitant psoriasis vulgaris and relevant psoriasis arthritis are present, treatment with TNF-alpha antagonists is particularly recommended.

\section{Infliximab}

Table 12 Tabular summary

Infliximab

First approved in Germany

Recommended control parameters

Recommended initial dosage

Recommended maintenance dosage

Expected beginning of clinical effect

Response rate

Important contraindications (limited selection)

Important ADRs (limited selection)

Important drug interactions (limited selection)

Other

\section{Instructions for application}

Pre-treatment

- Exclusion of acute and chronic infections, absolute exclusion of tuberculosis in accordance with the current recommendations of the Paul Ehrlich Institute (www.pei.de)

- Reliable contraception and exclusion of pregnancy in women of childbearing age

- Patients should be informed about the risk of severe infections.

- Hand out user information and special comment card to patients

\section{During treatment}

- Monitoring during infusion and 1-2 hours thereafter

- Monitoring for infections; the therapy should at least be temporarily discontinued when an infection is suspected

\section{Post-treatment}

- In women of childbearing age, contraception for up to 6 months after infliximab therapy 
Table 13 Laboratory controls during treatment with infliximab

\begin{tabular}{|c|c|c|c|}
\hline $\begin{array}{l}\text { Period in months } \rightarrow \\
\text { Diagnostics } \downarrow\end{array}$ & Before & 1 & 2 \\
\hline Complete blood count ${ }^{\mathrm{a}}$ & $\mathrm{x}$ & \multicolumn{2}{|c|}{ Prior to start of therapy and before every infusion } \\
\hline AST, ALT & $\mathrm{x}$ & \multicolumn{2}{|c|}{ Prior to start of therapy and before every infusion } \\
\hline Pregnancy test (urine) & $\mathrm{x}$ & & \\
\hline
\end{tabular}

${ }^{\mathrm{a}} \mathrm{Hb}, \mathrm{HCT}$, erythrocytes, leukocytes, differential blood count, platelets

\section{General assessment}

Of the seven studies evaluated, four fulfill the Guidelines' inclusion criteria. $^{[110-113]}$

Approximately $88 \%$ of the patients with moderate to severe psoriasis showed a PASI reduction of $75 \%$ after 10 weeks infliximab treatment with a dose of $5 \mathrm{mg} / \mathrm{kg} \mathrm{BW}$ in the normal therapy intervals (LE 1).

Infliximab is currently one of the most effective drugs for the treatment of psoriasis vulgaris. On the basis of the data available from long-term studies, good efficacy is also expected in the long-term therapy of psoriasis vulgaris.

A number of safety aspects should be considered with infliximab. Amongst these are, above all, infusion reactions and the risk of severe infection. This requires a careful evaluation of the indication, education, as well as monitoring of the patient.

As a result of the large number of patients treated with infliximab for other indications, the risk of adverse drug reactions can be estimated very well.

\section{Therapeutic recommendation}

Infliximab is recommended for the induction therapy of moderate to severe psoriasis vulgaris and severe, special forms of psoriasis which cannot be controlled by other therapeutic options or if, on the basis of the severity of the disease, a rapid resolution is required.

If concomitant psoriasis vulgaris and relevant psoriasis arthritis are present, treatment with TNF-alpha antagonists is particularly recommended.

\section{Cyclosporine}

Table 14 Tabular summary

Cyclosporine

First approved in Germany

Recommended control parameters

Recommended initial dosage

Recommended maintenance dosage

Expected beginning of clinical effect

Response rate

Important

contraindications (limited selection)
1983 (Transplantation medicine)

1993 (Psoriasis vulgaris)

Interview/examination:

- Status of skin and mucous membranes

- Signs of infection

- Neurological, gastrointestinal symptoms

- Blood pressure

Laboratory controls: see Table 14

2.5-3 (max. 5) $\mathrm{mg} / \mathrm{kg} \mathrm{BW}$

Interval therapy (between 8 and 16 weeks) with dosage reduction at the end of the induction therapy (e.g., $0.5 \mathrm{mg} / \mathrm{kg}$ BW every 14 days) or

Continuous long-term therapy with dosage reduction (e.g. by $50 \mathrm{mg}$ every 4 weeks after week 12) and a dosage increase by $50 \mathrm{mg}$ with relapse

Maximum total duration of therapy: 2 years

After approximately 4 weeks

Dose-dependent: after 8-16 weeks with $3 \mathrm{mg} / \mathrm{kg}$ BW; PASI 90 in approximately $30-50 \%$ of patient and PASI 75 in approximately 50$70 \%$ of patients (LE 1)

\section{Absolute:}

Reduced renal function, insufficiently controlled arterial hypertension, uncontrolled infections, relevant malignancies (current or previous, in particular hematologic diseases and cutaneous malignancies with the exception of basal cell carcinoma)

\section{Relative:}

Relevant hepatic dysfunction, pregnancy and nursing, concomitant use of substance which interacts with cyclosporine, concomitant UVtherapy or prior PUVA-pre-therapy with cumulative dosage $>1000 \mathrm{~J} /$ $\mathrm{cm}^{2}$, concomitant application of other immunosuppressives, retinoids or long-term prior-therapy with methotrexate (MTX) 
Table 14 continued

\begin{tabular}{|c|c|}
\hline \multicolumn{2}{|l|}{ Cyclosporine } \\
\hline $\begin{array}{l}\text { Important ADRs (limited } \\
\text { selection) }\end{array}$ & $\begin{array}{l}\text { Renal failure, increase of blood } \\
\text { pressure, liver failure, nausea, } \\
\text { anorexia, vomiting, diarrhea, } \\
\text { hypertrichosis, gingival hyperplasia, } \\
\text { tremor, weariness, parasthesia, } \\
\text { hyperlipidemia }\end{array}$ \\
\hline \multirow{7}{*}{$\begin{array}{l}\text { Important drug } \\
\text { interactions (limited } \\
\text { selection) }\end{array}$} & $\begin{array}{l}\text { Increase of the cyclosporine level } \\
\text { (CYP3A inhibition) through: }\end{array}$ \\
\hline & $\begin{array}{l}\text { Allopurinol, calcium antagonists, } \\
\text { amiodarone, antibiotics (macrolides, } \\
\text { clarithromycin, josamycin, } \\
\text { ponsinomycin, pristinamycin, } \\
\text { doxycycline, gentamicin, } \\
\text { tobramycin, ticarcillin, quinolones), } \\
\text { ketoconazole, oral contraceptives, } \\
\text { methylprednisolone (high dosages), } \\
\text { ranitidine, cimetidine, grapefruit } \\
\text { juice }\end{array}$ \\
\hline & $\begin{array}{l}\text { Decrease of the cyclosporine level } \\
\text { (CYP3A induction) through: } \\
\text { Carbamazepine, phenytoin, } \\
\text { barbiturates, metamizole, St. John's } \\
\text { wort }\end{array}$ \\
\hline & $\begin{array}{l}\text { Possible reinforcement of nephrotoxic } \\
\text { adverse drug reactions through: } \\
\text { Aminoglycosides, amphotericin B, } \\
\text { ciprofloxacin, acyclovir, non- } \\
\text { steroidal antiphlogistics }\end{array}$ \\
\hline & Specific interactions: \\
\hline & $\begin{array}{l}\text { Potassium-saving substances: increased } \\
\text { risk of hyperpotassemia }\end{array}$ \\
\hline & $\begin{array}{l}\text { Reduced clearance of: Digoxin, } \\
\text { colchicine, prednisolone, HMG-CoA } \\
\text { reductase inhibitors (e.g. lovastatin), } \\
\text { diclofenac }\end{array}$ \\
\hline \multirow[t]{3}{*}{ Other } & $\begin{array}{l}\text { Increased risk of lympho-proliferative } \\
\text { diseases in transplant patients. } \\
\text { Increased risk of squamous cell } \\
\text { carcinoma in psoriasis patients } \\
\text { following excessive phototherapy. }\end{array}$ \\
\hline & $\begin{array}{l}\text { Only moderately effective in and not } \\
\text { approved for psoriatic arthritis }\end{array}$ \\
\hline & $\begin{array}{l}\text { Also used successfully in the therapy of } \\
\text { chronic-inflammatory diseases in } \\
\text { children }\end{array}$ \\
\hline
\end{tabular}

\section{Instructions for application}

Pre-treatment

History

- Previous and concomitant diseases (e.g. severe infections, malignancies, renal and liver diseases), concomitant medications (see Drug Reactions)

Questions/examination

- Examination for skin malignancies

- Indications of existing infections

- Measurement of the blood pressure at two different times

Laboratory controls (see Table 3.5.2.2)

\section{Consultation}

$\checkmark$ Reliable contraception (cave: reduced efficacy of progesterone-containing contraceptives)

- Vaccination, susceptibility to infections [take infections seriously and, if needed, early presentation (e.g., visit GP)]

- Drug interactions (inform other treating physicians about therapy)

- Avoid excessive sun exposure, use of light-protection measures

\section{Measures during the therapy}

\section{Questions/examination}

- Status of skin and mucous membranes (e.g., increase of body hair, gingival hyperplasia)

$\checkmark$ Signs of infections

- Gastrointestinal or neurological symptoms

- Repeat recommendation for light avoidance and protection from sun light

- Check concomitant medications

- Measure blood pressure

Laboratory controls (see Table 3.5.2.2)

- With an uncomplicated long-term therapy with low dose (2.5$3 \mathrm{mg} / \mathrm{kg}$ BW daily) control intervals may later be extended to 2 months

- Short intervals (e.g., in patients with risk factors), dosage increases with the intake of metabolic drugs or with regard to the ADRs of interacting drugs

- Creatinine clearance in cases of implausible creatinine plasma levels

- In selected patients with intermittent and short-term treatment, a smaller number of controls (e.g., regular controls of blood pressure and creatinine assay) may be sufficient

- Determination of the cyclosporine level is recommended in individual cases

\section{Measures after therapy}

\section{None}


Table 15 Laboratory controls during treatment with cyclosporine

\begin{tabular}{|c|c|c|c|c|c|c|}
\hline $\begin{array}{l}\text { Period in weeks } \rightarrow \\
\text { Diagnostics } \downarrow\end{array}$ & Before & 2 & 4 & 8 & 12 & 16 \\
\hline Complete blood count & $t^{a} x$ & $\mathrm{x}$ & $\mathrm{x}$ & $\mathrm{x}$ & $x$ & $\mathrm{x}$ \\
\hline Liver values $^{\mathrm{b}}$ & $\mathrm{x}$ & $\mathrm{x}$ & $\mathrm{x}$ & $\mathrm{x}$ & $\mathrm{x}$ & $\mathrm{x}$ \\
\hline Electrolytes $^{c}$ & $\mathrm{x}$ & $\mathrm{x}$ & $\mathrm{x}$ & $\mathrm{x}$ & $\mathrm{x}$ & $\mathrm{x}$ \\
\hline Serum creatinine & $\mathrm{x}$ & $\mathrm{x}$ & $\mathrm{x}$ & $\mathrm{x}$ & $\mathrm{x}$ & $\mathrm{x}$ \\
\hline Urea & $\mathrm{x}$ & $\mathrm{x}$ & $\mathrm{x}$ & $\mathrm{x}$ & $\mathrm{x}$ & $\mathrm{x}$ \\
\hline $\begin{array}{l}\text { Urinanalysis and } \\
\text {-sediment }\end{array}$ & $\mathrm{x}$ & & $\mathrm{x}$ & $\mathrm{x}$ & $\mathrm{x}$ & $\mathrm{x}$ \\
\hline Uric acid & $\mathrm{x}$ & $\mathrm{x}$ & $\mathrm{x}$ & $\mathrm{x}$ & $\mathrm{x}$ & \\
\hline $\begin{array}{l}\text { Pregnancy test } \\
\text { (urine) }\end{array}$ & $\mathrm{x}$ & & & & & \\
\hline $\begin{array}{l}\text { Cholesterol, } \\
\text { triglycerides }^{d}\end{array}$ & $\mathrm{x}$ & & & $\mathrm{x}$ & & $\mathrm{x}$ \\
\hline Magnesium ${ }^{e}$ & $x$ & & & $\mathrm{x}$ & & $\mathrm{x}$ \\
\hline
\end{tabular}

${ }^{\text {a }}$ Erythrocytes, leukocytes, platelets

${ }^{\mathrm{b}}$ ALT, AST, AP (alkaline phosphatase), $\gamma$ GT (gamma glutamyl transpeptidase), bilirubin

${ }^{\mathrm{c}}$ Sodium, potassium

${ }^{\mathrm{d}}$ Recommended twice (fasting) and week-2 and 0

e Only with indication (e.g. muscle cramps)

\section{General assessment}

Of 65 studies evaluated with respect to the efficacy of a cyclosporine monotherapy in psoriasis, 15 studies fulfilled the Guidelines' inclusion criteria. ${ }^{[86,114-127]}$ Cyclosporine demonstrated a high effectiveness in the therapy of adults in these clinical studies. After 12-16 weeks, $50-70 \%$ of the patients achieved a PASI 75 (LE 1).

Cyclosporine is primarily suited for induction therapy; in long-term therapy a careful and individual weighing of the risks and benefits must be performed due to the adverse drug reactions, especially the nephrotoxicity and increase in blood pressure as well as the possibility of an increased risk of malignancies.

With the application of cyclosporine, a variety of drug reactions need to be considered, which on the one hand lead to a change in the availability of cyclosporine or concomitant medications, and on the other hand might increase the risk of adverse drug reactions.

As a result of its long-term use for various indications, including psoriasis vulgaris, an extensive body of data is available - also in terms of safety during long-term therapy with cyclosporine.

Cyclosporine represents an effective therapy for moderate and severe psoriasis vulgaris.

\section{Therapeutic recommendation}

Cyclosporine is primarily recommended for induction therapy for moderate to severe psoriasis vulgaris in adults who cannot be sufficiently treated with a topical therapy and/or phototherapy. In these cases, there is an acceptable risk-benefit ratio.

Cyclosporine can also be used for the long-term therapy of suitable patients over a period of up to 2 years maximum, whereby an increasing toxicity and a decreasing efficacy should be considered.

A combination with topical preparations for the treatment of psoriasis vulgaris is possible and reasonable, especially because there are signs that combining cyclosporine with topical vitamin $\mathrm{D}_{3}$-analogues or corticosteroids may allow a dose reduction of cyclosporine without a loss of efficacy.

\section{Fumaric acid esters}

Table 16 Tabular summary

Fumaric acid esters

First approved in 1995 (Psoriasis vulgaris)

Germany

Recommended control parameters

Recommended initial dosage

Recommended maintenance dosage

Expected beginning of clinical effect

Response rate

Important contraindications (limited selection)

Important ADRs (limited selection)

Important drug interactions

Other

Serum creatinine, transaminases $/ \gamma \mathrm{GT}$, complete blood count including differential blood count, urinanalysis

According to recommended dosage regimen see Table 17

Individually adapted dosage

After approximately 6 weeks

PASI 75 in $50-70 \%$ of the patients at the end of the induction phase after 16 weeks (LE 2)

Chronic diseases of the gastrointestinal tract and/or the kidneys and chronic diseases, which are accompanied by an impairment of the leukocyte count or functions, malignant diseases, pregnancy and nursing

Gastrointestinal complaints, flush, lymphopenia, eosinophilia

None known

Table 17 Dosage regimen for Fumaderm therapy

\begin{tabular}{lll}
\hline & Fumaderm initial & Fumaderm \\
\hline Week 1 & $1-0-0$ & \\
Week 2 & $1-0-1$ & \\
Week 3 & $1-1-1$ & \\
Week 4 & & $1-0-0$ \\
Week 5 & & $1-0-1$ \\
Week 6 & & $1-1-1$ \\
Week 7 & & $2-1-1$ \\
Week 8 & & $2-1-2$ \\
Week 9 & & $2-2-2$ \\
\hline
\end{tabular}




\section{Instructions for application}

Pre-treatment

Laboratory controls (see Table 3.5.3.3)

During treatment

Laboratory controls (see Table 3.5.3.3)

Post-treatment

$\checkmark$ None

Table 18 Laboratory controls during treatment with fumaric acid esters

\begin{tabular}{|lccc|}
\hline $\begin{array}{l}\text { Period in weeks } \rightarrow \\
\text { Diagnostics } \downarrow\end{array}$ & Pre-treatment & $\begin{array}{c}\text { Month 1-6 } \\
\text { every } 4 \text { weeks }\end{array}$ & $\begin{array}{c}\text { After month } 6 \\
\text { every } 8 \text { weeks }\end{array}$ \\
\hline Complete blood count ${ }^{\mathrm{a}}$ & $\mathrm{x}$ & $\mathrm{x}$ & $\mathrm{x}$ \\
\hline ALT, AST,, $\mathrm{GT}$ & $\mathrm{x}$ & $\mathrm{x}$ & $\mathrm{x}$ \\
\hline Serum creatinine & $\mathrm{x}$ & $\mathrm{x}$ & $\mathrm{x}$ \\
\hline Urinanalysis & $\mathrm{x}$ & $\mathrm{x}$ & $\mathrm{x}$ \\
\hline
\end{tabular}

${ }^{a}$ Leukocytes, platelets, erythrocytes, differential blood count

\section{General assessment}

Of 13 studies evaluated, nine fulfilled the Guidelines' inclusion criteria. ${ }^{[128-136]}$ After 16 weeks, $50-70 \%$ of the patients had a PASI 75 (LE 2).

There was good efficacy in the induction therapy and in the longterm therapy.

The therapy of psoriasis vulgaris with fumaric acid esters represents an effective systemic treatment which demonstrates a high level of long-term safety.

The tolerance is limited by adverse gastrointestinal drug reactions and flush symptoms.

The risk-benefit analysis of fumaric acid esters is positive, the practicality for both patients and physicians is good, and the costbenefit ratio is acceptable.

Positive aspects of the therapy with fumaric acid esters are the low number of drug interactions, the lack of immunosuppressive effects, the absence of increased susceptibility to infection, and the absence of any risk of malignancies during the long-term therapy.

A combination with topical medications for the treatment of psoriasis vulgaris is recommendable.

\section{Therapeutic recommendation}

Treatment with fumaric acid esters is recommended as an effective induction therapy for moderate to severe psoriasis vulgaris in adults.

Their application is primarily limited by gastrointestinal ADRs. A combination with any topical drugs for the treatment of psoriasis vulgaris is possible and reasonable.

Because of the favorable risk-benefit profile with good tolerability during long-term therapy, fumaric acid esters are highly recommended. 


\section{Methotrexate}

Table 19 Tabular summary

Methotrexate

First approved in Germany

$$
\begin{aligned}
& \text { Lantarel }^{\circledR} \\
& \text { Metex }^{\circledR} 7.5 / 10 \mathrm{mg} \\
& \text { Metex }^{\circledR} 2.5 \mathrm{mg}
\end{aligned}
$$

Recommended control parameters

Recommended initial
dosage
Recommended
maintenance dosage
Expected beginning
of clinical effect

Important
contraindications
(limited selection)

mportant ADRs (limited selection)
Table 19 continued

\begin{tabular}{ll}
\hline Methotrexate & \\
\hline $\begin{array}{l}\text { Important drug } \\
\text { interactions (limited } \\
\text { selection) }\end{array}$ & $\begin{array}{c}\text { Cyclosporine, salicylates, } \\
\text { sulfonamides, probenecide, } \\
\text { penicillin, colchicin, NSAIDs } \\
\text { (naproxene, ibuprofene, etc.), } \\
\text { ethanol, co-trimoxazole, } \\
\text { pyrimethamine, chloramphenicol, } \\
\text { sulfonamides, prostaglandin } \\
\text { synthesis inhibitors, cytostatics, } \\
\text { probenecide, barbiturates, phenytoin, } \\
\text { retinoids, sulfonamides, } \\
\text { sulfonylurea, tetracyclines, co- } \\
\text { trimoxazol, chloramphenicol, } \\
\text { dipyridamole, retinoids, ethanol, } \\
\text { leflunomide } \\
\text { Consistent avoidance of alcohol, X-ray } \\
\text { of the lungs prior to beginning } \\
\text { therapy }\end{array}$ \\
Other &
\end{tabular}

\section{5-22.5 mg per week depending on} effect

After 4-8 weeks

PASI 75 in approximately $60 \%$ of the patients at the end of the induction phase of 16 weeks (LE 3)

\section{Absolute contraindications:}

Desire to have children (for both men and women), pregnancy and nursing, inadequate contraception, drug consumption, alcoholism, known sensitivity to active ingredient methotrexate (e.g. pulmonary toxicity), bone marrow dysfunction, severe liver disease, severe infections, immunodeficiency, active peptic ulcers, hematologic changes (leucopenia, thrombocytopenia, anemia), renal failure

\section{Relative contraindications:}

Kidney disorders, liver disorders, history of arsenic consumption, chronic congestive cardio-myopathy, adiposity, old age, diabetes mellitus, history of hepatitis, lack of patient compliance, ulcerative colitis, diarrhea, NSAID use, gastritis

Liver fibrosis/cirrhosis, pneumonia/ alveolitis, bone marrow depression, renal damage, alopecia (reversible), nausea, weariness, vomiting, elevated transaminases, infection, gastrointestinal ulcerations, nephrotoxicity 


\section{Instructions for application}

$\underline{\text { Pre-treatment }}$

Anamnesis

Exclusion of alcohol abuse

Physical examination

- Sonography of liver following indication, i.e., with a positive anamnesis or pathological findings in the physical examination Examine for skin signs of chronic hepatic disease

Laboratory controls (see Table 3.5.4.2)

- An assay of the type III procollagen amino terminal propeptide (PIIINP) in serum is recommended

Imaging procedures

- Chest $\mathrm{x}$-ray (as necessary comparative image for the occurrence of pulmonary changes)

\section{Other}

- Information about intake (only on 1 day a week) and early symptoms of potential ADRs

\section{During treatment}

- Adequate contraceptive measures (for the treatment of both men and women)

- Laboratory controls (see Table 3.5.4.2)

- With dosage increases and an increased risk of an elevated MTX concentration (dehydration, reduced renal function, new medications) controls are performed more frequently

- An assay of type III procollagen amino terminal propeptide (PIIINP) in serum is recommended

- Liver biopsy: as soon as there is a longer treatment period following a cumulative dose of more than $1.5 \mathrm{~g}$ or more or if liver damage is suspected, a hepatologist should be consulted to determine whether a liver biopsy is needed ${ }^{[73,76]}$

- Chest x-ray: for complaints such as fever, coughing, dyspnoea, and cyanosis; important: MTX pneumonitis

- For the general reduction of toxicity, $5 \mathrm{mg}$ per day folic acid can be recommended on the days when there is no MTX intake

$\checkmark$ Careful registration of cumulative dose

\section{Post-treatment}

- Reliable contraceptive measures for at least 3 months after therapy in both men and women
Table 20 Laboratory controls during treatment with MTX [137]

\begin{tabular}{|c|c|c|c|c|}
\hline $\begin{array}{l}\text { Period in weeks } \rightarrow \\
\text { Diagnostics } \downarrow\end{array}$ & $\begin{array}{c}\text { Before } \\
\text { treatment }\end{array}$ & $\begin{array}{l}\text { First month: } \\
\text { 1 x/week }\end{array}$ & $\begin{array}{l}\text { 2nd - 3rd month } \\
1 \times / 2 \text { weeks }\end{array}$ & $\begin{array}{l}\text { After 4th month } \\
\text { every 2-3 months }\end{array}$ \\
\hline Complete blood count ${ }^{\mathrm{a}}$ & $\mathrm{x}$ & $\mathrm{x}$ & $\mathrm{x}$ & $\mathrm{x}$ \\
\hline Liver values $^{b}$ & $\mathrm{x}$ & $\mathrm{x}$ & $\mathrm{x}$ & $\mathrm{x}$ \\
\hline Creatinine/urea & $x$ & $x$ & $x$ & $\mathrm{x}$ \\
\hline Urine sediment & $\mathrm{x}$ & $\mathrm{x}$ & $\mathrm{x}$ & $\mathrm{x}$ \\
\hline Pregnancy test (urine) & $x$ & & & \\
\hline Liver sonography ${ }^{c}$ & $\mathrm{x}$ & & & \\
\hline Chest X-ray & $\mathrm{x}$ & & & \\
\hline Hepatitis B, C serology & $\mathrm{x}$ & & & \\
\hline $\begin{array}{l}\text { Type III procollagen } \\
\text { amino terminal propeptide } \\
\text { (PIIINP) }\end{array}$ & $x$ & & $\begin{array}{l}\text { hen every } 3 \\
\text { nonths }\end{array}$ & \\
\hline
\end{tabular}

${ }^{a} \mathrm{Hb}, \mathrm{HCT}$, erythrocytes, leukocytes, differential blood count, platelets

${ }^{\mathrm{b}}$ ALT, AST, AP, $\gamma \mathrm{GT}$, albumin, bilirubin, lactate dehydrogenase (LDH)

${ }^{\mathrm{c}}$ Liver biopsy instead of a liver sonography in risk groups

\section{General assessment}

Of 11 MTX monotherapy studies assessed for efficacy in psoriasis vulgaris, three studies fulfilled the Guidelines' inclusion criteria. ${ }^{[123,}$ 138, 139].

After a 16-week therapy with MTX, approximately $60-75 \%$ of the patients displayed a $75 \%$ reduction of the PASI score (LE 3).

Clinical experience with MTX is much greater than the documentation of the efficacy and safety of a MTX therapy in clinical studies.

Clinical experience has demonstrated that with longer treatment, the efficacy continues to increase and MTX therefore represents, above all, an effective therapeutic option for long-term therapy.

The clinical application is restricted by severe ADRs including, in particular, hepatotoxicity, nephrotoxicity, bone marrow suppression, gastrointestinal ulcerations and very rare, but severe idiosyncratic reactions.

With precise patient selection, thorough patient information, strict monitoring, administration of the lowest effective dosage (max. $22.5 \mathrm{mg}$ per week) and the additional administration of folic acid or folinic acid, an acceptable safety profile can also be attained for MTX therapy.

MTX provides the lowest drug costs per day of all the systemic therapeutics.

\section{Therapeutic recommendation}

MTX is effective in the treatment of moderate to severe psoriasis vulgaris; its use is limited by the contraindications and numerous controls needed during therapy.

MTX is, as a result of its slow onset of action, less recommendable for short-term induction therapy than for long-term therapy. 


\section{Retinoids}

Table 21 Tabular summary

Acitretin

First approved in
Germany
Recommended control
parameters
parameters Recommended initial
dosage

Recommended maintenance dosage

Expected beginning of clinical effect

Response rate

Important contraindications (limited selection)

Important ADRs (limited selection)

Important drug interactions (limited selection)

Other
1992 (Psoriasis vulgaris)

Erythrocyte sedimentation rate (ESR), complete blood count, liver values, renal values, blood lipid values, pregnancy test, $\mathrm{x}$-ray control of the bones in case of long-term therapy

$0.3-0.5 \mathrm{mg} / \mathrm{kg}$ BW per day for approximately 4 weeks, then $0.5-$ $0.8 \mathrm{mg} / \mathrm{kg} \mathrm{BW}$

Individual dosaging dependent on the results and tolerance

After 4-8 weeks

Widely variable and dose-dependent, no definite statement possible, partial remission (PASI 75) in 25$75 \%$ of the patients $(30-40 \mathrm{mg}$ per day) (LE 3) in studies

Renal and liver damage, desire to have children in female patients of childbearing age, pregnancy, nursing, alcohol abuse, manifest diabetes mellitus, wearing of contact lenses, history of pancreatitis, hyperlipidemia requiring drug treatment

Hypervitaminosis A (e.g., cheilitis, xerosis, nose-bleeding, alopecia, increased skin fragility)

Phenytoin, tetracyclines, methotrexate, alcohol, mini-pill

Contraception up to 2 years after discontinuation in female patients of child-bearing age

\section{Instructions for application}

\section{Pre-treatment}

\section{Anamnesis}

- Exclusion of pregnancy/nursing ${ }^{\mathrm{a}}$ (patient must be informed expressly and extensively about the teratogenic risk of the medication, the necessity of effective and long-term contraception, and the possible consequences of a pregnancy while taking retinoids); written documentation of the patient information interview

- Alcohol consumption (women of child-bearing age may not drink alcohol during and up to 2 months after treatment with acitretin)

- Exclusion of alcohol abuse

- Question regarding bone aches and aches in joints

- Laboratory controls (see Table 3.5.5.2)

\section{During treatment}

- With long-term treatment (approximately 1-2 years): radiological control examinations of the spine and joints are recommended if signs and symptoms develop to exclude possible occurrence of ossification

- Reliable contraception in women of child-bearing age

- For women of child-bearing age: No alcohol consumption during therapy

$\checkmark$ Laboratory controls (see Table 3.5.5.2)

\section{Post-treatment}

- Patients may not donate blood for up to 1 year after the discontinuation of therapy

- Reliable contraception in women of child-bearing age up to 2 years after therapy

- For women of child-bearing age: no alcohol consumption up to 2 months after end of therapy

${ }^{\text {a }}$ Double contraception is recommended (e.g., condom + pill; IUD/Nuva-Ring + pill; cave: no low-dosed progesterone preparations/mini-pills) during and up to 2 years after the end of therapy; effectiveness is reduced by acitretin 
Table 22 Laboratory controls during treatment with Acitretin

\begin{tabular}{|c|c|c|c|c|}
\hline $\begin{array}{l}\text { Period in weeks } \rightarrow \\
\text { Diagnostics } \downarrow\end{array}$ & eatment & 4 & 8 & 16 \\
\hline Complete blood count $^{a}$ & $\mathrm{x}$ & & $x$ & $\mathrm{x}$ \\
\hline AST, ALT, AP, yGT & $\mathrm{x}$ & $\mathrm{x}$ & $x$ & $\mathrm{x}$ \\
\hline Creatinine, urea & $\mathrm{x}$ & & & \\
\hline Triglycerides, cholesterol, $\mathrm{HDL}^{\mathrm{b}}$ & $\mathrm{x}$ & $x$ & & $\mathrm{x}$ \\
\hline $\begin{array}{l}\text { Pregnancy test (urine) } \\
\text { (monthly up to } 2 \text { years after therapy) }\end{array}$ & $\mathrm{x}$ & Monthly & & \\
\hline
\end{tabular}

${ }^{\mathrm{a}} \mathrm{Hb}, \mathrm{HCT}$, leukocytes, platelets

${ }^{\mathrm{b}}$ Preferably assayed twice (week-2 and 0); HDL, high-density lipidoprotein

\section{General assessment}

Of 52 studies assessed, four fulfilled the Guidelines' inclusion criteria in terms of a monotherapy and another four in terms of a combination therapy.

As a result of the very heterogeneous study results, it is not possible to make a clear statement regarding the efficacy of a monotherapy with acitretin (LE 3).

The effectiveness of retinoids in lower dosages as a monotherapy in moderate to severe psoriasis vulgaris is not satisfactory.

Higher dosages result in an increase of the efficacy, but these are frequently accompanied by increased ADRs in the skin and mucous membranes.

In women of childbearing age, the teratogenity, the monthly pregnancy tests, and the need for contraception for up to 2 years after the termination of the therapy severely limit the use of acitretin. An advantage of treatment with retinoids is the synergistic effect in combination with UV light. There is, however, insufficient evidence available on the basis of the studies included to recommend this approach.

\section{Therapeutic recommendation}

Acitretin is not recommended as a monotherapy because of lack of efficacy.

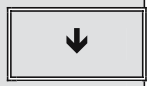

The application of higher dosages, which are more effective, is limited because of frequent adverse drug reactions.

The treatment of plaque psoriasis with acitretin in women of child-bearing age is strongly discouraged.

\section{Other therapies}

\section{Climate/balneotherapy}

Table 23 Tabular summary

Climate/balneotherapy

First approved in Germany

Clinical experience with balneotherapy has existed for more than 200 years

Recommended control Regular skin inspection parameters

Recommended initial Therapy regimens vary depending on the dosage

Recommended maintenance dosage institution/location

Therapy regimens vary depending on the Expected beginning of clinical effect

Response rate

Important contraindications

Important ADRs

Important drug interactions

Other institution/location

Varies greatly

Varies greatly (LE 4)

Dependent on modality selected

Dependent on modality selected

Not applicable

Balneotherapy and climate therapy are frequently combined

\section{General assessment}

Of 33 studies assessed, three fulfilled the Guidelines" inclusion criteria. ${ }^{[144-146]}$. This translates into a level of evidence 4.

The onset of clinical effect and the response rate vary greatly. For that reason, it is not possible to provide exact figures.

Balneotherapy and climate therapy have been successfully applied for the treatment of psoriasis vulgaris for centuries and are frequently used in combination with other therapies.

These are treatment modalities which have been developed over the years, but for which only very preliminary scientific data are available.

In the case of a combined strategy using natural phototherapeutic principles, efficacy and safety are similar to those of simple phototherapy.

Balneotherapy and climate therapy are tied to certain geographic regions and the specialized facilities located there.

\section{Therapeutic recommendation}

Balneotherapy and climate therapy have a special place in the framework of the long-term management of psoriasis vulgaris.

The integration of appropriate therapy phases into the treatment concept of patients with psoriasis vulgaris requiring treatment for years can be recommended.

These methods are not indicated for acute treatment or short-term therapy. 


\section{Psychosocial therapy}

\section{General assessment}

Of eight studies evaluated, three fulfilled the Guidelines' inclusion criteria. ${ }^{[77,147,148]}$ This resulted in a level of evidence 4 .

These studies of an additive, psychosocial treatment of psoriasis patients with the evidence grade $\mathrm{B}$ or $\mathrm{C}$ and with a large random sample selection as well as a relatively large dropout rates do not allow for any final conclusions to be drawn with respect to the efficacy of these therapies.

The low number of adverse events is certainly an advantage.

With a psychosocial treatment like Psoriasis Symptom Management or patient training, direct effects on skin symptoms can be achieved through, for example, improved stress management, and indirect effects on the development of the psoriasis can be achieved through, for example, improved compliance.

These two forms of therapy should be further investigated empirically.

\section{Therapeutic recommendation}

The possible impacts of the disease on social, emotional and psychic aspects should be considered for every psoriatic patient.

Information on existing self-help groups is recommended.

The possibility of participating in a structured training program in accordance with the recommendations of the ADP (Arbeitsgemeinschaft Dermatologische Prävention) of the DDG should be pointed out.

If the suffering is very intense or in cases of repeated clear exacerbation of the psoriasis vulgaris with stress, evaluation by an appropriate specialist with training in psychosomatics or psychotherapy can be offered if the patient so desires and, if necessary, psychosocial therapy initiated.

\section{Notes on the use of the Guidelines}

The presentation of the therapies deliberately focused on those aspects deemed particularly relevant by a panel of experts. Aspects which are not of specific importance for a certain intervention, but which are part of the physician's general obligations to the patient, such as the investigation of intolerance and allergies toward certain drugs or the exclusion of contraindications, are not individually listed, but it is nevertheless taken for granted that these are part of the physician's duty to provide care.

It is recommended that each and every user carefully reads and follows the product information and compare it with the recommendations in the Guidelines on dosaging, contraindications, and drug interactions for completeness and currentness. Every dose or application is administered at the user's own risk. The authors and the publishers kindly request that users inform them of any inaccuracies that they might notice. The users are requested to keep themselves constantly informed of any new findings subsequent to the publication of the Guidelines.

Acknowledgments The guidelines were generated upon request by the Deutsche Dermatologische Gesellschaft (DDG) and the Berufsverband Deutscher Dermatologen (BVDD). The project was supported by the 'Förderverein der Deutschen Dermatologischen Gesellschaft', the funding body of the DDG.

Conflicts of interests All authors have filled in specific forms to declare their conflicts of interests. These forms are available online under www.psoriasis-leitlinie.de. The experts involved in drawing up these guidelines received no payments for their work other than travel expenses.

\section{References}

1. Richards HL, Fortune DG, O'Sullivan TM, Main CJ, Griffiths CE (1999) Patients with psoriasis and their compliance with medication. J Am Acad Dermatol 41(4):581-583

2. Nevitt GJ, Hutchinson PE (1996) Psoriasis in the community: prevalence, severity and patients' beliefs and attitudes towards the disease. Br J Dermatol 135(4):533-537

3. Schmid-Ott G, Malewski P, Kreiselmaier I, Mrowietz U (2005) Psychosoziale Folgen der Psoriasis-eine empirische Studie über die Krankheitslast bei 3753 Betroffenen. Hautarzt 56(5):466-472

4. Rapp SR, Feldman SR, Exum ML, Fleischer AB Jr, Reboussin DM (1999) Psoriasis causes as much disability as other major medical diseases. J Am Acad Dermatol 41(3 Pt 1): 401-407

5. Stern RS, Nijsten T, Feldman SR, Margolis DJ, Rolstad T (2004) Psoriasis is common, carries a substantial burden even when not extensive, and is associated with widespread treatment dissatisfaction. J Invest Dermatol Symp Proc 9(2):136-139

6. Carroll CL, Clarke J, Camacho F, Balkrishnan R, Feldman SR (2005) Topical tacrolimus ointment combined with $6 \%$ salicylic acid gel for plaque psoriasis treatment. Arch Dermatol 141(1):43-46 
7. Agarwal R, Saraswat A, Kaur I, Katare OP, Kumar B (2002) A novel liposomal formulation of dithranol for psoriasis: preliminary results. J Dermatol 29(8):529-532

8. Monastirli A, Georgiou S, Pasmatzi E, Sakkis T, Badavanis G, Drainas D, Sagriotis A, Tsambaos D (2002) Calcipotriol plus short-contact dithranol: a novel topical combination therapy for chronic plaque psoriasis. Skin Pharmacol Appl Skin Physiol 15(4):246-251

9. Gerritsen MJ, Boezeman JB, Elbers ME, van de Kerkhof PC (1998) Dithranol embedded in crystalline monoglycerides combined with phototherapy (UVB): a new approach in the treatment of psoriasis. Skin Pharmacol Appl Skin Physiol 11(3):133-139

10. Prins M, Swinkels OQ, Van de Kerkhof PC, Van der Valk PG (2001) The impact of the frequency of short contact dithranol treatment. Eur J Dermatol 11(3):214-218

11. Thune P, Brolund L (1992) Short- and long-contact therapy using a new dithranol formulation in individually adjusted dosages in the management of psoriasis. Acta Derm Venereol Suppl 172:28-29

12. De Mare S, Calis N, den Hartog G, van Erp PE, van de Kerkhof PC (1988) The relevance of salicylic acid in the treatment of plaque psoriasis with dithranol creams. Skin Pharmacol 1(4):259-264

13. Prins M, Swinkels OQ, Bouwhuis S, de Gast MJ, BouwmanBoer Y, van der Valk PG, van de Kerkhof PC (2000) Dithranol in a cream preparation: disperse or dissolve? Skin Pharmacol Appl Skin Physiol 13(5):273-279

14. Hutchinson PE, Marks R, White J (2000) The efficacy, safety and tolerance of calcitriol $3 \mathrm{microg} / \mathrm{g}$ ointment in the treatment of plaque psoriasis: a comparison with short-contact dithranol. Dermatology 201(2):139-145

15. Mahrle G, Schulze HJ (1990) The effect of initial external glucocorticoid administration on cignolin treatment of psoriasis. Z Hautkr 65(3):282, 285-287

16. Agrup G, Agdell J (1985) A comparison between Antraderm stick $(0.5 \%$ and $1 \%)$ and dithranol paste $(0.125 \%$ and $0.25 \%)$ in the treatment of psoriasis. Br J Clin Pract 39(5):185-187

17. Swinkels OQ, Prins M, Kucharekova M, de Boo T, Gerritsen MJ, van der Valk PG, van de Kerkhof PC (2002) Combining lesional short-contact dithranol therapy of psoriasis with a potent topical corticosteroid. Br J Dermatol 146(4):621-626

18. Gottlieb AB, Ford R, Spellman MC (2003) The efficacy and tolerability of clobetasol propionate foam $0.05 \%$ in the treatment of mild to moderate plaque-type psoriasis of nonscalp regions. J Cutan Med Surg 7(3):185-192

19. Chuang TY, Samson CR (1991) Clinical efficacy and safety of augmented betamethasone dipropionate ointment and diflorasone ointment for psoriasis-a multicentre, randomized, doubleblinded study. J Dermatol Treat 2(2):63-66

20. Katz HI, Tanner DJ, Cuffie CA, Brody NI, Garcia CJ, Lowe NJ, Medansky RS, Roth HL, Shavin JS, Swinyer LJ (1998) A comparison of the efficacy and saftey of the combination mometasone furoate $0,1 \% /$ salicylic acid $5 \%$ ointment with each of its components in psoriasis. J Dermatol Treat 9(3):151-156

21. Koo J, Cuffie CA, Tanner DJ, Bressinck R, Cornell RC, DeVillez RL, Edwards L, Breneman DL, Piacquadio DJ, Guzzo CA, Monroe EW (1998) Mometasone furoate 0.1\%-salicylic acid $5 \%$ ointment versus mometasone furoate $0.1 \%$ ointment in the treatment of moderate-to-severe psoriasis: a multicenter study. Clin Ther 20(2):283-291

22. Camarasa JM, Ortonne JP, Dubertret L (2003) Calcitriol shows greater persistence of treatment effect than betamethasone dipropionate in topical psoriasis therapy. J Dermatol Treat $14(1): 8-13$
23. Papp KA, Guenther L, Boyden B, Larsen FG, Harvima RJ, Guilhou JJ, Kaufmann R, Rogers S, van de Kerkhof PC, Hanssen LI, Tegner E, Burg G, Talbot D, Chu A (2003) Early onset of action and efficacy of a combination of calcipotriene and betamethasone dipropionate in the treatment of psoriasis. $\mathrm{J}$ Am Acad Dermatol 48(1):48-54

24. Douglas WS, Poulin Y, Decroix J, Ortonne JP, Mrowietz U, Gulliver W, Krogstad AL, Larsen FG, Iglesias L, Buckley C, Bibby AJ (2002) A new calcipotriol/betamethasone formulation with rapid onset of action was superior to monotherapy with betamethasone dipropionate or calcipotriol in psoriasis vulgaris. Acta Derm Venereol 82(2):131-135

25. Kaufmann R, Bibby AJ, Bissonnette R, Cambazard F, Chu AC, Decroix J, Douglas WS, Lowson D, Mascaro JM, Murphy GM, Stymne B (2002) A new calcipotriol/betamethasone dipropionate formulation (Daivobet) is an effective oncedaily treatment for psoriasis vulgaris. Dermatology 205(4): 389-393

26. Stein LF, Sherr A, Solodkina G, Gottlieb AB, Chaudhari U (2001) Betamethasone valerate foam for treatment of nonscalp psoriasis. J Cutan Med Surg 5(4):303-307

27. Decroix J, Pres H, Tsankov N, Poncet M, Arsonnaud S (2004) Clobetasol propionate lotion in the treatment of moderate to severe plaque-type psoriasis. Cutis 74(3):201-206

28. Lebwohl M, Sherer D, Washenik K, Krueger GG, Menter A, Koo J, Feldman SR (2002) A randomized, double-blind, placebo-controlled study of clobetasol propionate $0.05 \%$ foam in the treatment of nonscalp psoriasis. Int J Dermatol 41(5):269274

29. Peharda V, Gruber F, Prpic L, Kastelan M, Brajac I (2000) Comparison of mometasone furoate $0.1 \%$ ointment and betamethasone dipropionate $0.05 \%$ ointment in the treatment of psoriasis vulgaris. Acta Derm Venereol Croat 8(4):223-226

30. Shupack JL, Jondreau L, Kenny C, Stiller MJ (1993) Diflorasone diacetate ointment $0.05 \%$ versus betamethasone dipropionate ointment $0.05 \%$ in moderate-severe plaque-type psoriasis. Dermatology 186(2):129-132

31. Svensson ARI, Gisslen H, Nordin P, Gios I (1992) A comperative study of mometasone furoate oinment and betamethasone valerate ointment in patients with Psoriasis vulgaris. Curr Ther Res Clin Exp 52(3):390-396

32. Weston WL, Fennessey PV, Morelli J, Schwab H, Mooney J, Samson C, Huff L, Harrison LM, Gotlin R (1988) Comparison of hypothalamus-pituitary-adrenal axis suppression from superpotent topical steroids by standard endocrine function testing and gas chromatographic mass spectrometry. J Invest Dermatol 90(4):532-535

33. Medansky RS, Cuffie CA, Tanner DJ (1997) Mometasone furoate $0.1 \%$-salicylic acid $5 \%$ ointment twice daily versus fluocinonide $0.05 \%$ ointment twice daily in the management of patients with psoriasis. Clin Ther 19(4):701-709

34. Housman TS, Keil KA, Mellen BG, McCarty MA, Fleischer AB Jr, Feldman SR (2003) The use of $0.25 \%$ zinc pyrithione spray does not enhance the efficacy of clobetasol propionate $0.05 \%$ foam in the treatment of psoriasis. J Am Acad Dermatol 49(1):79-82

35. Bagatell F (1988) Management of psoriasis: a clinical evaluation of the dermatological patch, Actidermregistered trade mark, over a topical steroid. Adv Ther 5(6):291-296

36. Fabry H, Yawalkar SJ (1983) A comparative multicentre trial of halometasone ointment and fluocortolone plus fluocortolone caproate ointment in the treatment of psoriasis. J Int Med Res 11(Suppl 1):26-30

37. Belsito DV, Kechijian P (1982) The role of tar in Goeckerman therapy. Arch Dermatol 118(5): 319-321 
38. Diette KM, Momtaz K, Stern RS, Arndt KA, Parrish JA (1984) Role of ultraviolet A in phototherapy for psoriasis. J Am Acad Dermatol 11(3):441-447

39. LeVine MJ, Parrish JA (1982) The effect of topical fluocinonide ointment on phototherapy of psoriasis. J Invest Dermatol 78(2):157-159

40. Frost P, Horwitz SN, Caputo RV, Berger SM (1979) Tar gelphototherapy for psoriasis. Combined therapy with suberythemogenic doses of fluorescent sunlamp ultraviolet radiation. Arch Dermatol 115(7):840-846

41. Weinstein GD, Koo JY, Krueger GG, Lebwohl MG, Lowe NJ, Menter MA, Lew-Kaya DA, Sefton J, Gibson JR, Walker PS (2003) Tazarotene cream in the treatment of psoriasis: two multicenter, double-blind, randomized, vehicle-controlled studies of the safety and efficacy of tazarotene creams $0.05 \%$ and $0.1 \%$ applied once daily for 12 weeks. J Am Acad Dermatol 48(5):760-767

42. Gollnick H, Menter A (1999) Combination therapy with tazarotene plus a topical corticosteroid for the treatment of plaque psoriasis. Br J Dermatol 140(Suppl 54):18-23

43. Green L, Sadoff W (2002) A clinical evaluation of tazarotene $0.1 \%$ gel, with and without a high- or mid-high-potency corticosteroid, in patients with stable plaque psoriasis. J Cutan Med Surg 6(2):95-102

44. Koo JY, Martin D (2001) Investigator-masked comparison of tazarotene gel q.d. plus mometasone furoate cream q.d. vs. mometasone furoate cream b.i.d. in the treatment of plaque psoriasis. Int J Dermatol 40(3):210-212

45. Lebwohl M (2000) Strategies to optimize efficacy, duration of remission, and safety in the treatment of plaque psoriasis by using tazarotene in combination with a corticosteroid. J Am Acad Dermatol 43(2 Pt 3):S43-S46

46. Poulin YP (1999) Tazarotene $0.1 \%$ gel in combination with mometasone furoate cream in plaque psoriasis: a photographic tracking study. Cutis 63(1):41-48

47. Van de Kerkhof PC, Green C, Hamberg KJ, Hutchinson PE, Jensen JK, Kidson P, Kragballe K, Larsen FG, Munro CS, Tillman DM (2002) Safety and efficacy of combined high-dose treatment with calcipotriol ointment and solution in patients with psoriasis. Dermatology 204(3):214-221

48. Guenther L, Van de Kerkhof PC, Snellman E, Kragballe K, Chu AC, Tegner E, Garcia-Diez A, Springborg J (2002) Efficacy and safety of a new combination of calcipotriol and betamethasone dipropionate (once or twice daily) compared to calcipotriol (twice daily) in the treatment of psoriasis vulgaris: a randomized, double-blind, vehicle-controlled clinical trial. Br J Dermatol 147(2):316-323

49. Kragballe K, Noerrelund KL, Lui H, Ortonne JP, Wozel G, Uurasmaa T, Fleming C, Estebaranz JL, Hanssen LI, Persson LM (2004) Efficacy of once-daily treatment regimens with calcipotriol/betamethasone dipropionate ointment and calcipotriol ointment in psoriasis vulgaris. Br J Dermatol 150(6):11671173

50. Ortonne JP, Kaufmann R, Lecha M, Goodfield M (2004) Efficacy of treatment with calcipotriol/betamethasone dipropionate followed by calcipotriol alone compared with tacalcitol for the treatment of psoriasis vulgaris: a randomised, double-blind trial. Dermatology 209(4):308-313

51. Guenther LC, Poulin YP, Pariser DM (2000) A comparison of tazarotene $0.1 \%$ gel once daily plus mometasone furoate $0.1 \%$ cream once daily versus calcipotriene $0.005 \%$ ointment twice daily in the treatment of plaque psoriasis. Clin Ther 22(10):1225-1238

52. Lebwohl M, Yoles A, Lombardi K, Lou W (1998) Calcipotriene ointment and halobetasol ointment in the long-term treatment of psoriasis: effects on the duration of improvement. J Am Acad Dermatol 39(3):447-450

53. Diette KM, Momtaz TK, Stern RS, Arndt KA, Parrish JA (1984) Psoralens and UV-A and UV-B twice weekly for the treatment of psoriasis. Arch Dermatol 120(9):1169-1173

54. Ramsay CA, Schwartz BE, Lowson D, Papp K, Bolduc A, Gilbert M (2000) Calcipotriol cream combined with twice weekly broad-band UVB phototherapy: a safe, effective and UVB-sparing antipsoriatric combination treatment. The Canadian Calcipotriol and UVB Study Group. Dermatology 200(1):17-24

55. Ring J, Kowalzick L, Christophers E, Schill WB, Schopf E, Stander M, Wolff HH, Altmeyer P (2001) Calcitriol 3 microg g1 ointment in combination with ultraviolet $\mathrm{B}$ phototherapy for the treatment of plaque psoriasis: results of a comparative study. Br J Dermatol 144(3):495-499

56. Petrozzi JW (1983) Topical steroids and UV radiation in psoriasis. Arch Dermatol 119(3):207-210

57. Coven TR, Burack LH, Gilleaudeau R, Keogh M, Ozawa M, Krueger JG (1997) Narrowband UV-B produces superior clinical and histopathological resolution of moderate-to-severe psoriasis in patients compared with broadband UVB. Arch Dermatol 133:514-522

58. Snellman E, Klimenko T, Rantanen T (2004) Randomized halfside comparison of narrowband UVB and trimethylpsoralen bath. Acta Derm Venereol 84(2):132-137

59. Gordon PM, Diffey BL, Matthews JNS, Farr PM (1999) A randomised comparison of narrow-band TL-01 phototherapy and PUVA photochemotherapy for psoriasis. J Am Acad Dermatol 41:728-732

60. Leenutaphong V, Nimkulrat P, Sudtim S (2000) Comparison of phototherapy two times and four times a week with low doses of narrow-band ultraviolet $\mathrm{B}$ in Asian patients with psoriasis. Photodermatol Photoimmunol Photomed 16(5):202-206

61. Grundmann-Kollmann M, Ludwig R, Zollner TM, Ochsendorf F, Thaci D, Boehncke WH, Krutmann J, Kaufmann R, Podda M (2004) Narrowband UVB and cream psoralen-UVA combination therapy for plaque-type psoriasis. J Am Acad Dermatol 50(5):734-739

62. Katugampola GA, Rees AM, Lanigan SW (1995) Laser treatment of psoriasis. Br J Dermatol 133(6):909-913

63. Housman TS, Pearce DJ, Feldman SR (2004) A maintenance protocol for psoriasis plaques cleared by the $308 \mathrm{~nm}$ excimer laser. J Dermatol Treat 15(2):94-97

64. Trehan M, Taylor CR (2002) Medium-dose 308-nm excimer laser for the treatment of psoriasis. J Am Acad Dermatol 47(5):701-708

65. Feldman SR, Mellen BG, Housman TS, Fitzpatrick RE, Geronemus RG, Friedman PM, Vasily DB, Morison WL (2002) Efficacy of the 308-nm excimer laser for treatment of psoriasis: results of a multicenter study. J Am Acad Dermatol 46(6):900906

66. Parrish JA, Fitzpatrick TB, Tannenbaum L, Pathak MA (1974) Photochemotherapy of psoriasis with oral methoxsalen and longwave ultraviolet light. N Engl J Med 291:1207-1211

67. Kirby B, Buckley DA, Rogers S (1999) Large increments in psoralen-ultraviolet A (PUVA) therapy are unsuitable for fairskinned individuals with psoriasis. Br J Dermatol 140(4):661666

68. Buckley DA, Healy E, Rogers S (1995) A comparison of twiceweekly MPD-PUVA and three times-weekly skin typing-PUVA regimens for the treatment of psoriasis. $\mathrm{Br} \mathrm{J}$ Dermatol 133(3):417-422

69. Berg M, Ros AM (1994) Treatment of psoriasis with psoralens and ultraviolet A. A double-blind comparison of 8-methoxyp- 
soralen and 5-methoxypsoralen. Photodermatol Photoimmunol Photomed 10:217-220

70. Cooper EJ, Herd RM, Priestley GC, Hunter JA (2000) A comparison of bathwater and oral delivery of 8-methoxypsoralen in PUVA therapy for plaque psoriasis. Clin Exp Dermatol 25(2):111-114

71. Collins P, Rogers S (1992) Bath-water compared with oral delivery of 8-methoxypsoralen PUVA therapy for chronic plaque psoriasis. Br J Dermatol 127(4):392-395

72. Calzavara-Pinton PG, Ortel B, Honigsmann H, Zane C, De Panfilis G (1994) Safety and effectiveness of an aggressive and individualized bath-PUVA regimen in the treatment of psoriasis. Dermatology 189(3):256-259

73. Barth J, Dietz O, Heilmann S, Kadner H, Kraensel H, Meffert H, Metz D, Pinzer B, Schiller F (1978) Fotochemotherapie mit 8methoxypsoralen und UVA bei Psoriasis vulgaris. Dermatol Monatsschr 164(6):401-407

74. Khurshid K, Haroon TS, Hussain I, Pal SS, Jahangir M, Zaman T (2000) Psoralen-ultraviolet A therapy vs. psoralen-ultraviolet B therapy in the treatment of plaque-type psoriasis: our experience with fitzpatrick skin type IV. Int J Dermatol 39(11):865-867

75. Arnold WP, van Andel P, de Hoop D, de Jong-Tieben L, Visservan Andel M (2001) A comparison of the effect of narrow-band ultraviolet $\mathrm{B}$ in the treatment of psoriasis after salt-water baths and after 8-methoxypsoralen baths. Br J Dermatol 145(2):352354

76. Park YK, Kim HJ, Koh YJ (1988) Combination of photochemotherapy (PUVA) and ultraviolet B (UVB) in the treatment of psoriasis vulgaris. J Dermatol 15(1): 68-71

77. Kabat-Zinn J, Wheeler E, Light T, Skillings A, Scharf MJ, Cropley TG, Hosmer D, Bernhard JD (1998) Influence of a mindfulness meditation-based stress reduction intervention on rates of skin clearing in patients with moderate to severe psoriasis undergoing phototherapy (UVB) and photochemotherapy (PUVA). Psychosom Med 60(5):625-632

78. Frappaz A, Thivolet J (1993) Calcipotriol in combination with PUVA: a randomized double blind placebo study in severe psoriasis. Eur J Dermatol 3:351-354

79. Rogers S, Marks J, Shuster S, Briffa DV, Warin A, Greaves M (1979) Comparison of photochemotherapy and dithranol in the treatment of chronic plaque psoriasis. Lancet 1(8114):455-458

80. Vella Briffa D, Rogers S, Greaves MW, Marks J, Shuster S, Warin AP (1978) A randomized, controlled clinical trial comparing photochemotherapy with dithranol in the initial treatment of chronic plaque psoriasis. Clin Exp Dermatol 3(4):339-347

81. Parker S, Coburn P, Lawrence C, Marks J, Shuster S (1984) A randomized double-blind comparison of PUVA-etretinate and PUVA-placebo in the treatment of chronic plaque psoriasis. Br J Dermatol 110(2):215-220

82. Dover JS, McEvoy MT, Rosen CF, Arndt KA, Stern RS (1989) Are topical corticosteroids useful in phototherapy for psoriasis? J Am Acad Dermatol 20(5 Pt 1):748-754

83. Hanke CW, Steck WD, Roenigk HH Jr (1979) Combination therapy for psoriasis. Psoralens plus long-wave ultraviolet radiation with betamethasone valerate. Arch Dermatol 115(9):1074-1077

84. Koo JY, Lowe NJ, Lew-Kaya DA, Vasilopoulos AI, Lue JC, Sefton J, Gibson JR (2000) Tazarotene plus UVB phototherapy in the treatment of psoriasis. J Am Acad Dermatol 43(5 Pt 1):821-828

85. McBride SR, Walker P, Reynolds NJ (2003) Optimizing the frequency of outpatient short-contact dithranol treatment used in combination with broadband ultraviolet $\mathrm{B}$ for psoriasis: a randomized, within-patient controlled trial. $\mathrm{Br} \mathrm{J}$ Dermatol 149(6):1259-1265
86. Levell NJ, Shuster S, Munro CS, Friedmann PS (1995) Remission of ordinary psoriasis following a short clearance course of cyclosporin. Acta Derm Venereol 75(1):65-69

87. Petzelbauer P, Honigsmann H, Langer K, Anegg B, Strohal R, Tanew A, Wolff K (1990) Cyclosporin A in combination with photochemotherapy (PUVA) in the treatment of psoriasis. Br J Dermatol 123(5):641-647

88. Franchi C, Cainelli G, Frigerio E, Garutti C, Altomare GF (2004) Association of cyclosporine and $311 \mathrm{~nm} \mathrm{UVB}$ in the treatment of moderate to severe forms of psoriasis: a new strategic approach. Int J Immunopathol Pharmacol 17(3):401-406

89. Paul BS, Momtaz K, Stern RS, Arndt KA, Parrish JA (1982) Combined methotrexate-ultraviolet B therapy in the treatment of psoriasis. J Am Acad Dermatol 7(6):758-762

90. Morison WL, Momtaz K, Parrish JA, Fitzpatrick TB (1982) Combined methotrexate-PUVA therapy in the treatment of psoriasis. J Am Acad Dermatol 6(1):46-51

91. Caca-Biljanovska NG, V'Lckova-Laskoska MT (2002) Management of guttate and generalized psoriasis vulgaris: prospective randomized study. Croat Med J 43(6): 707-712

92. Saurat JH, Geiger JM, Amblard P, Beau J-C, Boulanger A, Claudy A et al (1988) Randomized double-blind multicenter study comparing acitretin-PUVA and placebo-PUVA in the treatment of severe psoriasis. Dermatoligica 177:218-224

93. Lauharanta J, Geiger JM (1989) A double-blind comparison of acitretin and etretinate in combination with bath PUVA in the treatment of extensive psoriasis. Br J Dermatol 121(1):107-112

94. Orfanos CE, Steigleder GK, Pullmann H, Bloch PH (1979) Oral retinoid and UVB radiation: a new, alternative treatment for psoriasis on an out-patient basis. Acta Derm Venereol 59(3):241-244

95. Calzavara-Pinton P (1998) Narrow band UVB (311 nm) phototherapy and PUVA photochemotherapy: a combination. J Am Acad Dermatol 38(5 Pt 1):687-690

96. Markham T, Rogers S, Collins P (2003) Narrowband UV-B (TL-01) phototherapy vs oral 8-methoxypsoralen psoralen-UVA for the treatment of chronic plaque psoriasis. Arch Dermatol 139(3):325-328

97. Calzavara-Pinton P, Ortel B, Carlino A, Honigsmann H, De Panfilis G (1992) A reappraisal of the use of 5-methoxypsoralen in the therapy of psoriasis. Exp Dermatol 1(1):46-51

98. Henseler T, Wolff K, Hönigsmann H, Christophers E (1981) Oral 8-methoxypsoralen photochemotherapy of psoriasis. The European PUVA Study: a cooperative study among 18 European centres. Lancet 11:853-857

99. Torras H, Aliaga A, Lopez-Estebaranz JL, Hernandez I, Gardeazabal J, Quintanilla E, Mascaro JM (2004) A combination therapy of calcipotriol cream and PUVA reduces the UVA dose and improves the response of psoriasis vulgaris. J Dermatol Treat 15(2):98-103

100. Hacker SM, Rasmussen JE (1992) The effect of flash lamppulsed dye laser on psoriasis. Arch Dermatol 128(6):853-855

101. Gordon KB, Papp KA, Hamilton TK, Walicke PA, Dummer W, Li N, Bresnahan BW, Menter A (2003) Efalizumab for patients with moderate to severe plaque psoriasis: a randomized controlled trial. JAMA 290(23):3073-3080

102. Lebwohl M, Tyring SK, Hamilton TK, Toth D, Glazer S, Tawfik NH, Walicke P, Dummer W, Wang X, Garovoy MR, Pariser D (2003) A novel targeted T-cell modulator, efalizumab, for plaque psoriasis. N Engl J Med 349(21):2004-2013

103. Leonardi CL, Papp KA, Gordon KB, Menter A, Feldman SR, Caro I, Walicke PA, Compton PG, Gottlieb AB (2005) Extended efalizumab therapy improves chronic plaque psoriasis: results from a randomized phase III trial. J Am Acad Dermatol 52(3 Pt 1):425-433 
104. Menter A, Gordon K, Carey W, Hamilton T, Glazer S, Caro I, Li N, Gulliver W (2005) Efficacy and safety observed during 24 weeks of efalizumab therapy in patients with moderate to severe plaque psoriasis. Arch Dermatol 141(1):31-38

105. Papp K, Bissonnette R, Krüger JG, Carey W, Gratton D, Gulliver WP, Lui $\mathrm{H}$ (2001) The treatment of moderate to severe psoriasis with a new anti-CD11a monoclonal antibody. J Am Acad Dermatol 45(5):665-674

106. Gottlieb AB, Gordon KB, Lebwohl MG, Caro I, Walicke PA, Li N, Leonardi CL (2004) Extended efalizumab therapy sustains efficacy without increasing toxicity in patients with moderate to severe chronic plaque psoriasis. J Drugs Dermatol 3(6):614-624

107. Gottlieb AB, Matheson RT, Lowe N, Krueger GG, Kang S, Goffe BS, Gaspari AA, Ling M, Weinstein GD, Nayak A, Gordon KB, Zitnik R (2003) A randomized trial of etanercept as monotherapy for psoriasis. Arch Dermatol 139(12):1627-1632; discussion 1632

108. Leonardi CL, Powers JL, Matheson RT, Goffe BS, Zitnik R, Wang A, Gottlieb AB (2003) Etanercept as monotherapy in patients with psoriasis. N Engl J Med 349(21):2014-2022

109. Costanzo A, Mazzotta A, Papoutsaki M, Nistico S, Chimenti S (2005) Safety and efficacy study on etanercept in patients with plaque psoriasis. Br J Dermatol 152(1):187-189

110. Antoni C, Krueger GG, de Vlam K, Birbara C, Beutler A, Guzzo C, Zhou B, Dooley LT, Kavanaugh A (2005) Infliximab improves signs and symptoms of psoriatic arthritis: results of the IMPACT 2 trial. Ann Rheum Dis 64(8):1150-1157

111. Gottlieb AB, Evans R, Li S, Dooley LT, Guzzo CA, Baker D, Bala M, Marano CW, Menter A (2004) Infliximab induction therapy for patients with severe plaque-type psoriasis: a randomized, double-blind, placebo-controlled trial. J Am Acad Dermatol 51(4):534-542

112. Chaudhari U, Romano P, Mulcahy LD, Dooley LT, Baker DG, Gottlieb AB (2001) Efficacy and safety of infliximab monotherapy for plaque-type psoriasis: a randomised trial. Lancet 357(9271): 1842-1847

113. Schopf RE, Aust H, Knop J (2002) Treatment of psoriasis with the chimeric monoclonal antibody against tumor necrosis factor alpha, infliximab. J Am Acad Dermatol 46(6):886-891

114. Koo J (1998) A randomized, double-blind study comparing the efficacy, safety and optimal dose of two formulations of cyclosporin, Neoral and Sandimmun, in patients with severe psoriasis. OLP302 Study Group. Br J Dermatol 139(1):88-95

115. Thaci D, Brautigam M, Kaufmann R, Weidinger G, Paul C, Christophers E (2002) Body-weight-independent dosing of cyclosporine micro-emulsion and three times weekly maintenance regimen in severe psoriasis. A randomised study. Dermatology 205(4):383-388

116. Mahrle G, Schulze HG, Färber L, Weidinger G, Steigleder GK (1995) Low-dose short-term cyclosporine versus etretinate in psoriasis: improvement of skin, nail and joint involvement. J Am Acad Dermatol 32(1):78-88

117. Ellis CN, Fradin MS, Messana JM, Brown MD, Siegel MT, Howland Hartley A (1991) Cyclosporine for plaque-type psoriasis. Results of a multidose, double-blind trial. N Engl J Med 324:277-284

118. Elder C, Moore M, Chang CT, Jin J, Charnick S, Nedelman J, Cohen A, Guzzo C, Lowe N, Simpson K (1995) Efficacy and pharmacokinetics of two formulations of cyclosporine in patients with psoriasis. J Clin Pharmacol 35:865-875

119. Engst R, Huber J (1989) Ergebnisse einer Cyclosporin-behandlung bei schwerer, chronischer Psoriasis vulgaris. Hautarzt 40:186-189

120. Laburte C, Grossman R, Abi-Rached J, Abeywickrama KM, Dubertret L (1994) Efficacy and safety of oral cyclosporine A
(CYA; Sandimmun) for long-term treatment of chronic severe plaque psoriasis. Br J Dermatol 130:366-375

121. Meffert H, Braeutigam M, Faerber L, Weidinger G (1997) Lowdose $(1,25 \mathrm{mg} / \mathrm{kg})$ cyclosporine A: treatment of psoriasis and investigation of the influence on lipid profile. Acta Derm Venereol Suppl 77:137-141

122. Finzi AF, Mozzanica N, Pigatto PD, Cattaneo A, Ippolito F (1993) Cyclosporine versus etretinate: Italian multicentre comparative trial in severe psoriasis. Dermatology 187(Suppl 1):818

123. Heydendael VM, Spuls PI, Opmeer BC, de Borgie CA, Reitsma JB, Goldschmidt WF, Bossuyt PM, Bos JD, de Rie MA (2003) Methotrexate versus cyclosporine in moderate-to-severe chronic plaque psoriasis. N Engl J Med 349(7):658-665

124. Reitamo S, Spuls P, Sassolas B, Lahfa M, Claudy A, Griffiths CE (2001) Efficacy of sirolimus (rapamycin) administered concomitantly with a subtherapeutic dose of cyclosporin in the treatment of severe psoriasis: a randomized controlled trial. $\mathrm{Br} \mathrm{J}$ Dermatol 145(3):438-445

125. Grossman RM, Thivolet J, Claudy A, Souteyrand P, Guilhou JJ, Thomas P, Amblard P, Belaich S, de Belilovsky C, de la Brassinne $M$ et al (1994) A novel therapeutic approach to psoriasis with combination calcipotriol ointment and very low-dose cyclosporine: results of a multicenter placebo-controlled study. $\mathbf{J}$ Am Acad Dermatol 31(1):68-74

126. Finzi AF, Mozzanica N, Cattaneo A, Chiappino G, Pigatto PD (1989) Effectiveness of cyclosporine treatment in severe psoriasis: A clinical and immunologic study. J Am Acad Dermatol 21:91-97

127. Higgins E, Munro C, Marks J, Friedmann PS, Shuster S (1989) Relapse rates in moderately severe chronic psoriasis treated with cyclosporine A. Br J Dermatol 121:71-74

128. Litjens NH, Nibbering PH, Barrois AJ, Zomerdijk TP, Van Den Oudenrijn AC, Noz KC, Rademaker M, Van De Meide PH, Van Dissel JT, Thio B (2003) Beneficial effects of fumarate therapy in psoriasis vulgaris patients coincide with downregulation of type 1 cytokines. Br J Dermatol 148(3):444-451

129. Altmeyer PJ, Matthes U, Pawlak F, Hoffmann K, Frosch PJ, Ruppert P, Wassilew SW, Horn T, Kreysel HW, Lutz G, Barth J, Rietzschel I, Joshi R (1994) Antipsoriatic effect of fumaric acid derivatives. Results of a multicentre double-blind study in 100 patients. J Am Acad Dermatol 30(6):977-981

130. Gollnick H, Altmeyer P, Kaufmann R, Ring J, Christophers E, Pavel S, Ziegler J (2002) Topical calcipotriol plus oral fumaric acid is more effective and faster acting than oral fumaric acid monotherapy in the treatment of severe chronic plaque psoriasis vulgaris. Dermatology 205(1):46-53

131. Kolbach DN, Nieboer C (1992) Fumaric acid therapy in psoriasis: results and side effects of 2 years of treatment. J Am Acad Dermatol 27(5 Pt 1):769-771

132. Nugteren-Huying WM, Schroeff JGvd, Hermans J, Suurmond D (1990) Fumaric acid therapy for psoriasis: a randomized, double-blind, placeFumaric acid therapy for psoriasis: a randomized, double-bo-controlled study. J Am Acad Dermatol 22:311312

133. Altmeyer P, Hartwig R, Matthes U (1996) Das Wirkungs-und Sicherheitsprofil von Fumarsäureestern in der oralen Langzeittherapie bei schwerer therapieresistenter Psoriasis vulgaris. Eine Untersuchung an 83 Patienten. Hautarzt 47(3):190-196

134. Bayard W, Hunziker T, Krebs A, Speiser P, Joshi R (1987) Peroral long-term treatment of psoriasis using fumaric acid derivative. Hautarzt 38(5):279-285

135. Carboni I, De Felice C, De Simoni I, Soda R, Chimenti S (2004) Fumaric acid esters in the treatment of psoriasis: an Italian experience. J Dermatol Treat 15(1):23-26 
136. Mrowietz U, Christophers E, Altmeyer P (1998) Treatment of psoriasis with fumaric acid esters: results of a prospective multicentre study. German Multicentre Study. Br J Dermatol 138(3):456-460

137. Roenigk HH Jr, Auerbach R, Maibach H, Weinstein G, Lebwohl M (1998) Methotrexate in psoriasis: consensus conference. J Am Acad Dermatol 38(3):478-485

138. Weinstein GD, Frost P (1971) Methotrexate for psoriasis. A new therapeutic schedule. Arch Dermatol 103:33-38

139. Nyfors A, Brodthagen H (1970) Methotrexate for psoriasis in weekly oral doses without any adjunctive therapy. Dermatologica 140:345-355

140. van de Kerkhof PC, Cambazard F, Hutchinson PE, Haneke E, Wong E, Souteyrand P, Damstra RJ, Combemale P, Neumann MH, Chalmers RJ, Olsen L, Revuz J (1998) The effect of addition of calcipotriol ointment (50 micrograms/g) to acitretin therapy in psoriasis. Br J Dermatol 138(1):84-89

141. Kragballe K, Jansen CT, Geiger JM, Bjerke JR, Falk ES, Gip L, Hjorth N, Lauharanta J, Mork NJ, Reunala T et al (1989) A double-blind comparison of acitretin and etretinate in the treatment of severe psoriasis. Results of a Nordic multicentre study Acta Derm Venereol 69(1):35-40

142. Gupta AK, Goldfarb MT, Ellis CN, Voorhees JJ (1989) Sideeffect profile of acitretin therapy in psoriasis. J Am Acad Dermatol 20(6): 1088-1093

143. Carlin CS, Callis KP, Krueger GG (2003) Efficacy of acitretin and commercial tanning bed therapy for psoriasis. Arch Dermatol 139(4):436-442
144. Halevy S, Giryes H, Friger M, Sukenik H (1997) Dead sea bath salt for the treatment of psoriasis vulgaris: a double- blind controlled study. J Eur Acad Dermatol Venereol 9(3):237-242

145. Robertson DB, McCarty JR, Jarratt M (1978) Treatment of psoriasis with 8-methoxypsoralen and sunlight. South Med J 71(11):1345-1349

146. Fleischer ABJ, Clark AR, Rapp SR, Reboussin DM, Feldman SR (1997) Commercial tanning bed treatment is an effective psoriasis treatment:results from an uncontrolled clinical trial. J Invest Dermatol 109(2):170-174

147. Fortune DG, Richards HL, Kirby B, Bowcock S, Main CJ, Griffiths CE (2002) A cognitive-behavioural symptom management programme as an adjunct in psoriasis therapy. $\mathrm{Br} \mathbf{J}$ Dermatol 146(3):458-465

148. Tausk F, Whitmore SE (1999) A pilot study of hypnosis in the treatment of patients with psoriasis. Psychother Psychosom 68(4):221-225

149. Nast A, Kopp I, Augustin M), Banditt KB, Boehncke WH, Follmann M, Friedrich M, Huber M, Kahl C, Klaus J, Koza J, Kreiselmaier I, Mohr J, Mrowietz U, Ockenfels HM, Orzechowski HD, Prinz J, Reich K, Rosenbach T, Rosumeck S, Schlaeger M, Schmid-Ott G, Sebastian M, Streit V, Weberschock T, Rzany B (2006) S3-Leitlinie zur Therapie der Psoriasis vulgaris. JDDG Suppl 2:S1-S126 